\title{
Industry-Level Labour Demand Elasticities Across the Eurozone: Will There Be Any Gain After the Pain of Internal Devaluation?
}

\author{
Antonis Adam \\ Thomas Moutos
}

CESIFO WORKING PAPER NO. 4858

CATEGORY 4: LABOUR MARKETS

JUNE 2014
An electronic version of the paper may be downloaded
- from the SSRN website: Www.SSRN.com
- from the RePEc website: Www.RePEc.org
- from the CESifo website: www.CESifo-group.org/wp

\section{CESifo}




\title{
Industry-Level Labour Demand Elasticities Across the Eurozone: Will There Be Any Gain After the Pain of Internal Devaluation?
}

\begin{abstract}
In this paper we estimate disaggregated labour demand equations using panel data involving observations across time (1970-2007) for twenty-three industries across eleven euro area countries. By using the EU KLEMS database, which provides data across countries, we provide industry-by-industry estimates of the labour demand function. The values of our estimated (own-price) elasticities of labour demand are substantial, and in accordance with the findings of the empirical literature. Independently of whether we use level or time-differenced data, the (absolute value of the) estimated conditional elasticities are bracketed in the interval $[0.05,0.80]$, with the (un-weighted) mean elasticity across the various methods ranging from 0.26 to 0.43 . The values of the estimated unconditional elasticities are similar in size and range, and the same holds true for country-specific wage-elasticities of labour demand. Our results indicate that the experienced wage declines in the periphery countries of the euro area can, when the contractionary credit and budgetary policies come to an end, have a nonnegligible, albeit modest, effect on future employment growth.
\end{abstract}

JEL-Code: F160, J230.

Keywords: labour demand, wages, international trade, euro area.

Antonis Adam

Department of Economics

University of Ioannina

P.O. Box 1186

Greece - Ioannina 45110

aadam@cc.uoi.gr
Thomas Moutos

Athens University of Economics

and Business

Patission 76

Greece - Athens 10434

tmoutos@aueb.gr

We gratefully acknowledge financial support from the Bank of Greece, and helpful comments and suggestions from Heather Gibson, Bob Hart, Dimitris Malliaropoulos, Daphne Nicolitsas, as well as participants at a Bank of Greece workshop presentation. 


\section{Introduction}

A common theme in the diagnoses and proposed cures regarding the dismal employment performance of the periphery countries of the Euro Area (EA12) ${ }^{1}$ since the onset of the Global Financial and Economic Crisis in 2007 has been the issue of price developments and labour costs (EEAG, 2011). Indeed, Greece, Ireland, Portugal, and Spain had, from 1999 to 2009 significantly higher increases in domestic inflation and unit labour costs indicators than the rest of the EA12 countries. The concomitant loss in (international) competitiveness for the periphery countries was associated with large current account deficits, whose correction necessitated - in the absence of nominal exchange rate adjustment - a deceleration of domestic price and wage increases (relative to the rest of the EA12 countries) or outright deflation.

In the absence of perfect (i.e. fast, and by the required amount) wage and price flexibility, the required recovery in competitiveness could only come about through a large enough recession and drop in employment ${ }^{2}$ so that price and wage setters are "incentivized" to set lower prices and wages. Once these (gradual) adjustments have been accomplished, one hopes that the gain in competitiveness will allow growth in output and employment to re-emerge along with a continuing improvement in public finances, and without the re-appearance of large current account deficits.

Given the very high unemployment rates experienced by the periphery economies (as high as 28 percent for Greece in November 2013), this paper aims at assessing the likely implications of reductions in labour cost on employment. We do this by estimating disaggregated labour demand equations using panels involving observations across

\footnotetext{
${ }^{1}$ EA12 denotes the twelve countries (Austria, Belgium, Finland, France, Germany, Greece, Ireland, Italy, Luxembourg, Netherlands, Portugal, and Spain) in which the euro coins and notes became legal tender in 01/01/2002.

${ }^{2}$ The recession in the periphery economies was (to different degrees across countries) a result of government budget consolidation and of a credit crunch due to the sudden stop in private capital inflows.
} 
time (37 years) and eleven countries ${ }^{3}$ for twenty-three manufacturing industries as classified by the KLEMS database.

Our focus on a cross-country panel is motivated by the increasing influence of international competition (aka globalization) on employment developments. Indeed, the likely effects of globalization on labour market outcomes have attracted considerable theoretical and empirical attention among economists (e.g. Wood, 1994; Krugman, 1995; Feenstra and Hansson, 1996 and 1999; Rodrik, 1997; Slaughter, 2001; Krishna et al, 2001; Hasan et al, 2007; Feenstra, 2010). For example, Rodrik (1997) has noted the link between the (own-price) labour demand elasticity and globalization by drawing attention to Hicks's fundamental law of factor demand, according to which " the demand for anything is likely to be more elastic, the more elastic is the demand for any further thing which it contributes to produce". Since product market elasticities have likely increased with trade liberalization, it is hypothesized that globalization has been accompanied by the increased sensitivity of employment to labour costs. ${ }^{4}$

However, the objective of the present study is not to examine the influence of globalization on labour market outcomes per se, but rather to use a group of countries which set similar trade and regulatory barriers to foreign competition (i.e. the EU countries) in order to discern the influence of differential wage developments across countries/industries on labour demand. For example, if one were to examine the relationship between wages and employment in a declining industry (e.g. textiles) in a single country, one may not be able to exploit the fact that all European Union (EU) countries face the same challenges from other countries' exports; the inclusion of many EU countries which face the same competitive pressure from non-EU countries (and

\footnotetext{
${ }^{3}$ We do not include Luxembourg in our data set due to the very small size of employment in many of the industries examined.

${ }^{4}$ Despite the intuitive appeal of the proposition that the demand-for-labor curve is more elastic when an economy is open than when it is closed, Panagariya (1999) has shown that it is not valid in general. He showed that the proposition can be violated in both the $2 \times 2$ and specific-factors models, and that many of the results obtained by Rodrik (1997), assuming the proposition to be true, fail to hold in general when we spell out the full structure of the model.
} 
from each other) allows us to discern whether, and to what extent, even in a declining industry, employment falls less in countries experiencing smaller wage increases.

To our knowledge, this is the first study of labour demand which explicitly uses information related to industry developments across many European countries in order to infer the size of (own-price) labour demand elasticities. ${ }^{5}$ In the past, due to lack of data, researchers had to rely on (within-country) industry panels. However, this raises some serious issues of interpretation since many relationships are known to vary across industries. The EU KLEMS database provides data across countries, which allows for estimations industry-by-industry so that the cross-section panel dimension in the data is the country, rather than the industry.

The values of our estimated (own-price) elasticities of labour demand elasticities are substantial, and in accordance with the findings of the empirical literature. Hamermesh (1993), in his extensive survey of estimated labour demand elasticities concluded that "We know that the absolute value of the constant-output (i.e. conditional) elasticity of demand for homogeneous labour for a particular firm, and for the aggregate economy in the long run, is above 0 and below 1 . Its value is probably bracketed by the interval $[0.15,0.75]$, with 0.30 being a good 'best guess'" (p. 135). Our results across the 23 industries examined corroborate this conclusion; independently of whether we use level or time-differenced data ${ }^{6}$, the estimated conditional elasticities ${ }^{7}$ are bracketed in the interval $[0.05,0.80]$, with the (un-weighted) mean elasticity across the various methods ranging from 0.26 to 0.43 .

\footnotetext{
${ }^{5}$ See, however, Pierluigi and Roma (2008) who estimate labour demand functions at the level of the total economy, as well as three sectors (manufacturing, construction, and services), for the five larger Eurozone economies (Germany, France, Italy, Spain, and The Netherlands).

${ }_{7}^{6}$ We report results for both three-year, and five-year differences.

${ }^{7}$ In the remainder of this paper, we will refer to an increase in the absolute value of the own- price elasticity of labour demand (not to an increase in its actual negative value) simply as an increase in labour demand elasticity. Moreover, when we quote elasticity values in the text - not in the Tables - we always quote their absolute value, and, unless specified otherwise, we always mean the own-price elasticity of labour demand when we refer to the labour-demand elasticity.
} 
The empirical work in this paper yields three main results. First, there is substantial heterogeneity among manufacturing industries with respect to labour demand elasticities (both conditional and unconditional). Second, the same heterogeneity applies (for the manufacturing sector) among countries, with Germany and Spain appearing as the countries with the highest elasticity across all specifications (their mean conditional elasticity for time-differenced data is 0.73 and 0.52 , respectively), whereas Belgium and France are the countries with the lowest elasticity (their mean conditional elasticity for time-differenced data are 0.05 and 0.11 , respectively). Third, the estimated values for the elasticity of labour demand are substantial from the perspective of policymakers, since, for example, they imply that wage reductions in the periphery countries of the Eurozone will have some discernible impact on manufacturing employment. Yet, since the estimated values for the elasticity are well below 1, which implies that the labour share will decline if wages decrease, trade-union leaders may resist the large decreases in wages required to restore the pre-crisis employment levels in the Eurozone periphery.

There are five more sections in this paper. Section 2 presents a broad picture of manufacturing-sector employment developments in the EA12. In Section 3 we discuss the theoretical considerations which guided our empirical analysis, whereas Section 4 presents the econometric equations to be estimated and the data used. Sections 5 and 6 present and explain the findings of our estimations for industries and countries, respectively. Section 7 concludes.

\section{A Brief Overview of Employment Developments in Manufacturing in EA12}

Total employment in manufacturing has been on a downward trend for the twelvecountry aggregate of EA12 since 1974, when it reached a peak at 29.31 million employees, up from 28.57 million in 1970 . The first oil crisis put a stop to the rise in manufacturing employment, which started decelerating at a faster pace after the second oil crisis; by 2007, manufacturing employment in the EA12 aggregate had 
dropped to 21.44 million employees. As a share of economy-wide employment, employment in manufacturing dropped from 34 percent in 1970 to 18 percent in 2007.

The drop in manufacturing employment has not been a feature shared by all EA12 countries (see Tables 1 and 2). Indeed, manufacturing employment declined considerably in the "core" Eurozone countries; by 2007, manufacturing employment in Belgium was only 52 percent of its 1970 level, whereas the corresponding percentage in France was 63 percent, in Germany 65 percent, in Netherlands 70 percent, in Austria 75 percent, and in Finland 84 percent. Although in some of these countries manufacturing employment had started declining even before the first oil shock, Table 1 reveals that both the first and the second oil shocks exercised a non-negligible influence on its evolution in all countries of this group.

\section{[Figure 1]}

In contrast, for the "periphery" countries of the EA12, there was either no decline in employment, or it was higher. Ireland and Spain experienced increases in manufacturing employment (by 22 and 11 percent, respectively, from 1970 to 2007), whereas, during the same period, Portugal, Italy, and Greece experienced declines in manufacturing employment by 13,9 , and 5 percent, respectively.

\section{[Figure 2]}

\section{[Figure 3]}

Similarly, the decline in employment was not equally borne among industries. As Figures 3 and 4 indicate - which portray the evolution of employment for the 8 largest industries in terms of employment from 1970 to 2007, the decline in employment was most pronounced in the "Textiles and Textile Products". This industry was, by far, the largest (manufacturing-sector) employer in 1970, accounting for 15 percent of total employment in manufacturing, and by 2007 it accounted for only 6 percent and had become the fourth-largest employer. The drop in textiles employment, and the rise in employment in "Motor Vehicles, Trailers, \& Semi-Trailers" and in "Rubber and Plastics", 
is just a manifestation of the comparative-advantage driven forces unleashed by globalization.

\section{[Figure 4]}

We note that these changes in employment were accompanied by a decline in the share of gross value added devoted to employee compensation for the manufacturing sector as a whole in EA12 - from 64 percent in 1970 to 60 percent in 2007 (Figure 5). However, the drop in the "labour share" ${ }^{8}$ was large in declining (in terms of employment) industries (e.g. in textiles the share dropped from 70 in 1970 to 64 percent in 2007), while it rose substantially in expanding industries (e.g. in rubber and plastics increased from 56 to 66 percent, while in motor vehicles increased from 65 to 69 percent during the same period). These changes in (relative) employee compensation are possibly indicative of the existence of rent-sharing mechanisms (see, e.g. Blanchflower and Oswald, 1994), but they could also reflect the rising cost of intermediate inputs.

\section{[Figure 5]}

The share of intermediate input purchases to the value of gross output did indeed rise from 64 percent in 1970 to 72 percent in 2007 for total manufacturing for the aggregate of EA12. As shown in Figure 6, the rise in the share of the value of intermediate inputs in the value of gross output kept apace even after $1995^{9}$ - when the influence of the oilprice shocks had subsided, thus signifying an increasing trend among firms to outsource part of their "non-core" production activities either to domestic or foreign suppliers (Sinn, 2006). Figure 5 also shows that there are large differences across industries in the

\footnotetext{
${ }^{8}$ This is only approximately equal to the labour share, since it refers only to the compensation of employees and not to the total labour compensation which includes non-salaried people (e.g. selfemployed) working in the industry in question.

${ }^{9}$ Although the data for Total Manufacturing are available for the aggregate of EA12 from 1970 onwards, the data for particular industries are not available before 1995 for all countries.
} 
(value) share of intermediate inputs in gross output, which could be one factor explaining differences in the elasticity of labour demand across sectors. ${ }^{10}$

\section{[Figure 6]}

Finally, the allocation of employment within countries has had some similarity across the economies we examine. As shown in Figure 7, Food and Beverages has been the largest employer - on average, over the entire period - among manufacturing sector industries for six countries (Austria, Belgium, Greece, Ireland, Netherlands, Spain), ${ }^{11}$ Fabricated Metals for two countries (France, Italy), Machinery NEC ${ }^{12}$ for two countries (Germany and Finland), and Wearing Apparel, Dressing and Dying of Fur for Portugal. These "patterns of specialization" continued to prevail in 2007 as well, with Food and Beverages still being the largest manufacturing-sector employer in six countries, as it lost its top position in Austria (to Machinery NEC), but gained the top position in France. We note that the patterns of inter-industry specialization that prevailed in 1970 were not much altered by 2007 for most countries; e.g. Machinery NEC was the top employer (within the manufacturing sector) in Germany for all years between 1970 and 2007, Fabricated Metals was for Italy during the whole period, and the same was true even for Ireland (for Food and Beverages), which went through a spectacular growth episode during this period.

\section{[Figure 7]}

\section{Theoretical Considerations for Empirical Specification}

In this section we briefly discuss the main theoretical considerations that guided our empirical analysis in light of our data, and proceed with stating our baseline empirical specifications.

\footnotetext{
${ }^{10}$ The EU KLEMS database also reveals that there were differences in the share of intermediate inputs to gross output - for a particular industry - across countries, but these were not as large as the ones between industries.

${ }^{11}$ Food and Beverages was the second biggest employer for Germany, Finland, France, and Portugal, and the third biggest in Italy.

${ }^{12}$ NEC: abbreviation for "not elsewhere classified".
} 


\subsection{Conditional Labour Demand}

Following Hamermesh (1993), Slaughter (2001), and Hasan et al (2007) we conceive that the conditional (i.e. cost-minimizing) labour demand curve of a perfectly competitive firm can be written as:

$$
L=L(w, r, m, Q) \text {, }
$$

where $w, r, m$, and $Q$ are the wage rate, the user cost of capital, the price of intermediate inputs, and the firm's output respectively. As noted by these authors, the cost-minimizing labour demand functions can be written in terms of nominal factor prices or equivalently in terms of real (i.e. deflated by the price of output) factor prices, since the price of output is taken as given for this problem. As a result, the nominal and real wage labour demand elasticities coming out of cost minimization are the same.

Hamermesh's (1993) proposal of a log-linear specification of conditional labour demand has been followed by many authors. For example, Slaughter (2001), Hasan et al (2007), and Hijzen and Swaim (2010) adopt the following specification for the unconditional labour demand:

$$
\ln L=\alpha+\beta \ln w+\gamma \ln r+\delta \ln m+\epsilon Q
$$

where $w, r$, and $m$ stand for the nominal factor prices.

\subsection{Profit-Maximizing Labour Demand}

Consider now the profit maximizing factor demands of a perfectly competitive firm. As shown by Hasan et al (2003), the profit-maximizing (i.e. the unconditional) labour demand function of the firm can be expressed as: ${ }^{13}$

$$
\ln L=\alpha+\beta \ln (w / P)+\gamma \ln (r / P)+\delta \ln (m / P)
$$

where $P$ stands for the price of output, which the firm considers exogenous.

\footnotetext{
${ }^{13}$ This derivation assumes an iso-elastic product demand curve and a Cobb-Douglas production function.
} 
However, from the point of view of the industry as a whole the price is endogenous. More specifically, for any given product demand curve, we expect the industry price to be affected by changes in (nominal) factor prices since the latter will influence the position of the industry's output supply curve. Hamermesh (1993) shows that the endogeneity of the industry's price to factor prices can be dealt with by using the market-clearing equation for the industry's output ${ }^{14}$ to substitute out the price. Doing so results in a labour demand function which has a form similar to equation (3), but now, for example, the econometric estimation of the corresponding parameter $\beta$ would stand for the elasticity of labour demand with respect to the nominal wage rate.

What if the industry in question comprises of monopolistically competitive firms? Again, as shown by Krishna et al (2001) and Hasan et al (2003), each firm's labour demand curve will be similar to equation (2), but now $P$ will stand for the industry's "price level" - which in an industry with a continuum of firms will be the price index of close substitutes. If our focus is on industry employment with $n$ identical firms, then the industry's labour demand equation will have a similar form. Nevertheless, the industry's price level will not be independent of factor prices and it would still be preferable to avoid the endogeneity concerns by specifying the labour demand function in terms of nominal factor prices. Thus following Hamermesh's (1993) suggestion, unconditional labour demand equations have been specified in terms of nominal factor prices (e.g. Slaughter, 2001; Hijzen and Swaim, 2010) ${ }^{15}$ :

$$
\ln L=\alpha+\beta \ln w+\gamma \ln r+\delta \ln m
$$

\footnotetext{
${ }^{14}$ Taking this endogeneity into account is important in our context since we have access only to industrylevel data.

${ }^{15}$ Hamermesh (1993) shows that the relationship between the unconditional $(\varepsilon)$ and the conditional $(v)$ own-price elasticity of labour demand is $\varepsilon=v+S_{L} \theta$, where $S_{L}$ is the share of labour in output and $\theta$ is the own-price elasticity of product demand. The term $S_{L} \theta$ is the scale effect, which is due to the fact that an increase in wages, by increasing the cost of production results in higher price and lower industry output, thus reducing the demand for labour beyond what is implied by factor substitution along an isoproduct surface.
} 
The above discussion has (implicitly) assumed that the industry's output is exclusively sold to the domestic market, and that the industry faces no competition from foreign producers. We now discuss the implications of two cases regarding the mode of international competition and the size of the domestic industry.

The first case can be thought of as involving many domestic producers of a homogeneous good, with the country in question being small in the world market for this good..$^{16}$ In such a situation, the domestic industry's price is exogenous and equal to the world price of the good. Any, e.g., rise in the wage paid by domestic firms will not affect the (world) price of the good, but will only reduce the output of domestic firms, and domestic employment, i.e. labour demand will be inversely related to the real wage. Similarly, an increased supply of the good by rest-of-the-world producers which results in a reduction in the price of the good would be associated with a rise in the real wage paid by domestic firms and reduced domestic employment. These observations imply that one can treat data pertaining to the domestic employment of an industry in a small open economy in the same way as one would treat data pertaining to employment and factor prices of individual firms in a closed economy (i.e. the labourdemand function can be specified in terms of real factor prices as in equation (2)).

The second case differs from the first in that the size of the domestic industry is large enough to influence the (world) price of the product (i.e. the large-country case in international trade), but still each domestic firm is small enough and takes the world price as given. In this case, a generalized change in factor costs across all domestic firms would be expected to influence the price of the good - thus it would be preferable to avoid potential endogeneity concerns by estimating labour demand as a function of nominal factor prices. ${ }^{17}$

\footnotetext{
${ }^{16}$ This is the typical structure assumed in the partial equilibrium analysis of international trade policies (e.g. Feenstra and Taylor, 2008).

${ }^{17}$ We do not examine other cases, i.e. those involving imperfect competition, since these cases provide no substantial differentiation as to the form of the labour demand function from the cases already discussed.
} 
What are the implications of the above discussion for the econometric specification we should adopt given our industry/country data? Given that the industries/countries covered in our sample involve cases where the domestic industry is either too small to affect international market outcomes (e.g. "scientific instruments" in Greece) or large enough to affect the evolution of prices and quantities worldwide (e.g. "motor vehicles" in Germany) we estimate unconditional labour demand equations as functions of either nominal or real factor prices (equations (3) and (4)).

\section{Estimation Framework and Data}

\subsection{Estimation Issues}

Based on the discussion of the previous section, we plan to estimate the following panels for cost-minimizing (CM), or constrained, and profit-maximizing (PM), or unconstrained, labour demand functions for each industry:

$\mathrm{CM}$ :

$$
\ln L_{i t}=a_{i}+\lambda_{t}+\beta_{1} \ln w_{i t}+\beta_{2} \ln m_{i t}+\beta_{3} \operatorname{prod}_{i t}+\beta_{4} Q_{i t}+u_{i t}
$$

PM1:

$$
\ln L_{i t}=a_{i}+\lambda_{t}+\beta_{1} \ln w_{i t}+\beta_{2} \ln m_{i t}+\beta_{3} \operatorname{prod}_{i t}+\beta_{4} R E E R_{i t}+u_{i t}
$$

$\mathrm{PM} 2: \quad \ln L_{i t}=a_{i}+\lambda_{t}+\beta_{1} \ln \frac{w_{i t}}{p_{i t}}+\beta_{2} \ln \frac{m_{i t}}{p_{i t}}+\beta_{3} \operatorname{prod}_{i t}+\beta_{4} R E E R_{i t}+u_{i t}$.

In the equations above, $i$ stands for the country index, $t$ for the time index, $L_{i t}$ for the number of employees, $w_{i t}$ for the compensation per employee, $m_{i t}$ for the price of intermediate inputs, $p_{i t}$ for the price of gross output, prod $_{i t}$ for the gross value added per employee, $R E E R_{i t}$ for the real effective exchange rate, whereas $a_{i}$ denotes the country specific fixed effect, and $\lambda_{t}$ is the time fixed effect. The time fixed effects are introduced in order to capture possible changes in world demand for the industry's product which are not fully captured by $R E E R_{i t}$, as well as changes in the common forces of international competition from the rest of the world that all EA12 countries have faced. On the other hand, the country fixed effect captures country specific differences in each industry (e.g. increased capability to produce higher-quality 
products, or to serve niche markets) as well as other country specific characteristics (e.g. product and labour market legislation and institutions).

A few remarks are in order about the specifications above. ${ }^{18}$ First, in the absence of good measures for the user cost of capital at the industry level, we opted for not including in our baseline specification any measures for capital costs. ${ }^{19}$ Nevertheless, we did experiment with including an (imperfect) measure of capital cost, i.e. the (real) interest rate on 10-year government bonds. The results were very similar to the ones obtained from our baseline specifications - e.g. the average difference in the estimates for the own-price labour demand elasticity between the baseline specifications and the ones including the measure of capital costs mentioned above was less than 0.05 ; for this reason, and taking into account that the degree of correlation between the return on government bonds and the true cost of capital for each industry may differ substantially across countries due to large differences in the average size of the firm among countries, ${ }^{20}$ we have opted to focus on our baseline specifications.

Second, in order to be able to interpret the estimated coefficients of the three equations as parameters of the labor demand function, we need to assume that the supply of labor to each industry-country unit is perfectly elastic, so that wages are exogenous. This may appear a strong assumption to make since we do not use firm-level data. However, it bears noting that our data pertain to each one of twenty-three

\footnotetext{
${ }^{18}$ These specifications assume that the unit of employment is an employee, and not, e.g. an hour of work (the same holds for the unit of compensation). Hart (1987) has argued persuasively that the latter measure is a better one. However, due to lack of data that extend back in time for some of the countries/industries examined, we have not pursued this issue further. Moreover, the potential existence of significant differences across countries and industries between paid-for and actual hours worked can introduce significant measurement error in actual hourly earnings. For example, Bell and Hart (1999) report that in the UK, the average weekly paid-for overtime was 1.7 hours, compared with 1.9 unpaid hours, according to the 1993/94 Labour Force Survey; this discrepancy implies that hourly pay based on paid-for hours was $£ 7.25$, but when unpaid overtime is included, the estimate falls to $£ 6.75$.

${ }^{19}$ An alternative which has been pursued by some authors (e.g. Berman et al., 1994; Hasan et al., 2007; Hijzen and Swaim, 2010) is to treat capital as a quasi-fixed factor and estimate capital-constrained labour demand equations. Since we do not have measures for the capital stock for all countries/industries of our study we have not pursued this route here.

${ }^{20}$ For example, the textiles industry in Greece has been dominated by small producers whose cost of capital is likely to be far less correlated with the return on government bonds than for larger producers in the "core" countries of the EA12.
} 
manufacturing industries, and as Figure 6 indicated, the highest share of any industry in total employment was, on average, the one observed for the Food and Beverages industry in Ireland (at 5.1 percent of total employment in the Irish economy). In fact, for all countries examined, there were - at most - only two industries in each country which were employing at any point in time more 3 percent of total employment. For this reason it is not a far-fetched assumption to think that each industry faces fairly elastic labour supply curves.

An alternative identification strategy which we have tried is to use instrumental variables, i.e. a variable that could be a plausible shifter of the labour supply equation, but which would not be expected to affect the position of the labour demand curve. In the absence of good instruments, we experimented with using as instruments the inflation rate, the unemployment rate, and wages in the public sector. In many cases the instruments performed poorly, whereas in industries where the instruments appeared to be valid a Hausman (1978) test could not reject the hypothesis of exogeneity. For these reasons we have decided to use the standard OLS fixed effects estimator. ${ }^{21}$

Third, the unconstrained labour demand curves are meant to capture both the substitution effect (i.e. a move along an isoquant as factor prices change) and the scale effect (i.e. the change in the firm's output, and employment, in response to changes in costs along a given (downward-sloping) product-demand curve). However, they are not meant to capture shifts in the product-demand curve itself. Thus, we include the real effective exchange rate in the unconstrained labour demand equations (6) and (7) as a way to capture such potential, country-specific, product-demand shifts.

Fourth, the inclusion of the labour productivity variable aims to control for shifts in labour demand arising from changes in firms' required labour to produce a given level of output, as well as in firms' ability to pay for labour services. ${ }^{22}$ For the output-

\footnotetext{
${ }^{21}$ We present below estimates based on time-differenced data as another method for dealing with potential endogeneity issues.

${ }^{22}$ An alternative specification which we have tried is to use the concept of unit labour cost - in both its nominal and real guises - as a substitute for the labour compensation and productivity measures. In both
} 
constrained labour demand equation, an exogenous increase in labour productivity e.g. through labour-augmenting technological change, would decrease a firm's labour demand. However, the effect can be positive for the unconstrained labour demand equation as the firm responds to the reduction in its costs by producing a higher level of output. $^{23}$

\subsection{Data}

The paper uses data from the March 2011 release of the EU KLEMS Growth and Productivity Accounts (EU KLEMS, 2011), which contain industry-level measures of output, inputs, wages, and productivity from 1970 to 2007 (see, O'Mahony and Timmer, 2009, for a detailed description of the database). For each of the 23 manufacturing industries included in our study the EU KLEMS database provides coverage for the number of employees, total compensation of employees, gross value added, and prices of output and intermediate inputs. ${ }^{24}$

The database includes time series for the numbers of all persons engaged in an industry and, separately, for the number of employees, with the difference between the two being the self-employed and family-workers. It bears noting that the ratio of employees to persons engaged differs across countries and across industries. For example, for manufacturing as a whole, the ratio of employees to persons engaged stood at 92 percent for the aggregate of EA12 in 1995, but the corresponding magnitude was only 65 percent in Greece. Similarly, for the aggregate of EA12, the same ratio was 99.5 percent for Motor Vehicles, Trailers, \& Semi-Trailers in 1995, but it stood at only 79 percent for Wood and of Wood and Cork in the same year. Given these large discrepancies between countries and across industries in the importance of self-

cases, there were a few industries with large and positive estimated elasticities (i.e. an increase in unit labour increases labour demand).

${ }^{23}$ Excluding the labour productivity measure from the equations produces estimates of the conditional own-price labour demand elasticities considerably larger (in absolute terms) than the unconditional elasticities for many industries; moreover in a few cases the estimated values are either positive or statistically insignificant.

${ }^{24}$ In cases where there are no data for a specific year we estimate an unbalanced panel. 
employment, and the fact that in the EU KLEMS Database it is assumed that the selfemployed (and family members) receive the same compensation as employees, we decided in order to avoid problems arising from significant compositional and measurement errors to focus on the labour demand for employees only.

The data for the REER are drawn from Darvas (2012), which is a consumer price index (CPI) based measure. We have opted for a CPI based measure since we did not want to introduce any correlation between the measure of labour compensation we would be using and the unit labour costs based measures of the REER.

\section{Results}

Given our focus on the own-price labour demand elasticity, and the number of countries and industries involved, we are not exhaustive in the presentation of our results with respect to the other determinants of labour demand. Moreover, we constrain the presentation of full results to only the largest eight (in terms of employment) manufacturing industries.

\subsection{Baseline Results for Selected Industries}

Table 1a presents the results from estimating the conditional (i.e. constant-output) labour demand (equation (5)). The theoretical priors are confirmed by these results since: (i) the (own-price) labour demand elasticity is, in all cases, negative and statistically significant, ${ }^{25}$ and (ii) the factor-substitution effect appears to be verified as a rise in the price of intermediate inputs boosts the demand for labour in all cases. The controls for labour productivity and output are also estimated to exert an influence which is not at variance with theoretical priors (negative for labour productivity and positive for output), although for half of the industries presented labour productivity does not appear to have a statistically significant influence on labour demand.

\section{[Table 1a]}

\footnotetext{
${ }^{25}$ We comment below on the size of the estimated elasticities.
} 
Table $1 \mathrm{~b}$ presents the results from estimating the unconditional labour demand equation specified in terms of real factor prices (equation (6)). The labour demand elasticities for all industries are negative and their mean value is larger than for the constrained case. The first thing to note in comparison with the results of Table 1 , is that, in congruence with theoretical priors, for six out of the eight industries, the unconstrained labour demand elasticity is significantly higher than the constrained one by as much as 0.5 in the case of Fabricated Metals. For Rubber and Plastics, and for Electrical Machinery the constrained elasticity is larger than the unconstrained by 0.08 , which contradicts standard theory but seems to be a common occurrence in other studies. For example, in Slaughter's (2001) study not only the mean unconstrained elasticity was larger than the constrained one, but also in only one-third of the cases examined the unconstrained elasticity was negative and statistically significant. Slaughter (2001) and Hasan et al. (2007) attribute this to the lack of good controls for shifts in product demand, something which appears to hold in the present study as well since our control for product-demand shifts (the real effective exchange rate) is a crude measure and in only one of the eight industries appears to exert a (statistically) significant influence on labour demand. We have also experimented with using the country's aggregate GDP, which, due to home-market effects, could shift the productdemand curve; this did not lead to any substantial change in the values of the estimated elasticities, i.e. the mean value changed by less than 0.02 .

\section{[Table 1b]}

An interesting contrast between the constrained and the unconstrained estimates is the change in the sign of the estimated elasticity for the price of intermediate inputs and labour productivity. Regarding the price of intermediate inputs, for all industries the estimated elasticities change from positive in the constrained case (i.e. the effect of factor substitution along an iso-product surface), to all of them being negative in the unconstrained case (as firms' output decreases due to rising costs). For the labour productivity variable the change is in the opposite direction (from negative in the 
constrained case to positive in the unconstrained case); this is understandable since in the unconstrained case firms respond to the reduction in costs that an increased productivity entails by increasing output. We note that the switch in the sign of the estimated elasticity of labour demand with respect to the price of intermediate inputs from the constrained to the unconstrained case gives us some confidence in believing that we are indeed uncovering labour-demand elasticities and not a combination of labour-demand and labour-supply elasticities.

\section{[Table 1c]}

Table 1c presents the results from estimating the unconditional labour demand equation specified in terms of nominal factor prices (equation (7)). The results are poorer in relation to the estimation involving real factor prices in many aspects. First, the labour demand elasticity for five out of the eight industries is not (statistically) significant. Second, for the three industries for which the elasticity is significant, in two cases (Food and Beverages, and Electrical Machinery) the unconstrained elasticity is smaller than the constrained one, which is contrary to theoretical priors, whereas in the other case (Textiles) they have the same magnitude. ${ }^{26}$ Third, the prices of intermediate inputs appear to exert a positive influence on labour demand for three industries, and an insignificant influence for the remaining five. ${ }^{27}$ On the basis of this evidence, but also on evidence from the full sample of industries examined, it appears that the specification of unconstrained labour demand as a function of real factor prices is superior to the one using nominal factor prices.

\subsection{Baseline Estimates of the Labour-Demand Elasticity for All Industries}

We now present the results of our estimates for the wage-elasticity of labour demand for all twenty-three industries examined. From Table 2 we can draw the following conclusions: First, the conditional labour demand elasticity is negative for all industries.

\footnotetext{
${ }^{26}$ In fact, the mean estimate for the unconstrained labour demand elasticity even when including the statistically insignificant ones is half the size of the mean estimate of the constrained estimates.

${ }^{27}$ The real effective exchange rate remains an insignificant determinant of labour demand for all industries concerned.
} 
The value of the estimated elasticities ranges from 0.21 (for Printing, Publishing and Reproduction) to 0.78 (for Recycling). The un-weighted mean value of these estimates is 0.43. Second, the unconditional estimates of the elasticity when the labour demand equation is estimated using real factor prices are all negative, with their value ranging from 0.25 (for Coke, Refined Petroleum and Nuclear Fuel) to 1.12 (for Wearing Apparel, Dressing And Dying Of Fur). The un-weighted mean value of these estimates is 0.59, and it is significantly higher than the mean estimate for the conditional elasticities. However, for three industries (Rubber and Plastics, Electrical Machinery, Recycling) the value of the estimated elasticity is higher than the conditional one. Third, the unconditional estimates of the elasticity when the labour demand equation is estimated using nominal factor prices are not always (significant and) negative, with their value ranging from 0.00 (Chemicals and Chemical Products) to 0.62 (Textiles). ${ }^{28}$ Their un-weighted mean value is 0.24 , which is significantly lower than the mean estimate for the conditional elasticities, and for no industry is the unconditional elasticity larger than the conditional one. These findings corroborate the results presented in the previous section. ${ }^{29}$

\section{[Table 2]}

\subsection{Estimates with Time-Differenced Data}

The estimates presented in the previous section in effect assume that firms are able to adjust labour demand in response to changes in factor prices or other shocks within a year. This assumption may not be a realistic one in the presence of significant firing and hiring costs (as well as of other elements of regulation which restrict the speed of adjustment by firms) - which seems to be the case for most of the countries examined

\footnotetext{
${ }^{28}$ Lawrence and Lawrence (1985) have argued that that declining industries (like, Chemicals and Chemical Products, and Textiles, in our case) realize less elastic labor demands - and thus more aggressive wage demands from their workers - because the substitutability between labor and capital declines when there is a decline in product demand.

${ }^{29}$ The results may also imply that, for the countries examined, the assumption that each country is small in the world market is a relatively good approximation. This statement does not preclude that some industries in some of the EA12 countries are large enough to affect world prices; it probably reflects only the fact that most of countries of the EA12 are indeed small in the world market for most goods.
} 
here. $^{30}$ By taking differences over a relatively long period (3-year, and 5-year differences) ${ }^{31}$ we in effect allow firms to have considerable time to adjust labour demand to disturbances. Moreover, as argued by Griliches and Hausman (1986), long difference estimators tend to be less sensitive to measurement error. Another advantage of long time-differences is that over longer time horizons the maintained identifying assumption of perfectly-elastic labor supplies is more likely to hold (Slaughter, 2001). This is due to the existence of firm- or industry-specific human capital, which makes labour supply less elastic in the short-run, but over longer-time horizons workers have more opportunities to assess whether the disturbances are temporary or permanent in nature, to re-train and move to other industries. Finally, changes in factor prices may induce entry or exit of firms - a process which is likely to take some time since investors would wish to make sure that any change in factor prices would be of a more permanent nature before making any (dis)investment decisions.

\section{[Table 3]}

The results of the estimation using 3-year and 5-year differences are presented in Tables 3 and 4 . We note the following things from comparing these two Tables with Table 2. First, the value of the estimated elasticities drops considerably as we move from the level to the time-differenced data; Wearing Apparel, Dressing And Dying Of Fur remains the industry with the highest elasticity (as high as 0.54), which is about half the size of the one appearing in Table 2. Second, there are no longer large differences in the values of the estimated elasticities as we shift between the two ways of estimating the unconditional elasticities. Whereas in Table 2 the difference in the estimated unconditional elasticities could be as large as 0.60 (for Wearing Apparel, Dressing And Dying Of Fur), the largest difference in Table 3 is 0.14 (for Wood and of Wood and Cork), and 0.13 in Table 4 (for Fabricated Metal); the mean difference in the estimated unconditional elasticities drops from 0.35 in Table 2, to 0.05 for the time-differenced

\footnotetext{
${ }^{30}$ After reviewing the literature Hamermesh (1993) concludes that employment responds less rapidly to cost or output shocks in Western Europe - possibly because the regulatory environment is heavier in Western Europe, but also because unionism is sparse and less effective in the United States.

${ }^{31}$ Using longer-time differences does not produce any significant difference to our results.
} 
cases. Third, there are no longer large differences in the values of the estimated elasticities between the conditional and unconditional cases. Whereas in Table 2 the difference between the estimated unconditional and conditional elasticities could be as large as 0.50 (for Fabricated Metal), the largest difference is 0.08 in Table 3 (for Printing, Publishing and Reproduction), and 0.12 in Table 4 ((for Wood and of Wood and Cork). Fourth, there are no (economically) significant differences in the values of the estimated elasticities between the 3-year and the 5-year differenced data; the difference in the mean estimated elasticity is 0.01 if we compare the conditional elasticities, and 0.02 if we compare the unconditional elasticities. ${ }^{32}$

\section{[Table 4]}

\section{Results for Countries}

The panel specification of equations (5) to (7) assumed that for each industry the underlying data-generating structure was the same for all countries, but differed between industries. According to this assumption all countries share the same technology which differs across industries. This allowed us to derive industry-specific elasticities which were common for all countries. We now wish to derive countryspecific elasticities under the assumption that the data-generating structure is common across industries but differs between countries. This implicitly assumes that technology is homogeneous across industries but differs across countries. Equations (5)' to (7)' are the analogue of equations (5) to (7), with the only difference being that now the subscript $i$ stands for industries rather than countries:

$$
\begin{aligned}
& \ln L_{i t}=a_{i}+\lambda_{t}+\beta_{1} \ln w_{i t}+\beta_{2} \ln m_{i t}+\beta_{3} \operatorname{prod}_{i t}+\beta_{4} Q_{i t}+u_{i t} \\
& \ln L_{i t}=a_{i}+\lambda_{t}+\beta_{1} \ln w_{i t}+\beta_{2} \ln m_{i t}+\beta_{3} \operatorname{prod}_{i t}+\beta_{4} R E E R_{i t}+u_{i t} \\
& \ln L_{i t}=a_{i}+\lambda_{t}+\beta_{1} \ln \frac{w_{i t}}{p_{i t}}+\beta_{2} \ln \frac{m_{i t}}{p_{i t}}+\beta_{3} \operatorname{prod}_{i t}+\beta_{4} R E E R_{i t}+u_{i t},
\end{aligned}
$$

\footnotetext{
${ }^{32}$ The largest difference in the values of the estimated elasticities between Tables 3 and 4 is 0.11 (for Recycling).
} 
In Tables 5a-5c, which display the wage-elasticity of labour demand in the manufacturing sector for each of the 11 countries, we observe the same pattern we noted for industries, i.e. the values of the elasticity are reduced as we shift from levels to time-differenced data, but there are no significant changes in the estimated elasticities between the 3-year and 5-year differenced data. Indeed, the difference in the mean value of the estimated elasticities between Tables $5 b$ and $5 c$ is only 0.01 , whereas the largest difference is 0.11 (for Austria). Comparing Table 5a with Tables 5b and $5 c$ we observe that when we do not use in our estimations time-differenced data, for 4 countries (France, Germany, Greece, Netherlands) the estimated (absolute) value of the conditional elasticity is significantly larger than the values of the unconditional elasticity; with time-differenced data the estimated values of the conditional elasticity drop considerably, ${ }^{33}$ and the only country for which the estimate for the conditional elasticity is larger than the unconditional estimates is Finland. ${ }^{34}$ We note that for timedifferenced data, there is a very small difference (up to 0.04 for all specifications) in the mean value of the estimated elasticities between Table 2 (which refers to industries) and Table 5, whereas the smallest estimated unconditional elasticities are zero (for Italy) and 0.03 (for Belgium), and the largest are 0.52 (for Spain) and 0.72 (for Germany).

\section{[Table 5]}

The differences in the values of the elasticities across countries are large, but not easy to interpret. One possible explanation is industrial specialization. However, as mentioned in Section 2, the data do not reveal large differences in industrial

\footnotetext{
${ }^{33}$ For Italy and France, the value of the estimated elasticity drops by 0.80 and 0.70 (respectively), whereas for Finland it rises by 0.15 .

${ }^{34}$ A point of clarification is needed at this juncture. Although at the level of a firm it is clear that the unconditional elasticity of labour demand is larger than the conditional elasticity (Cahuc and Zylberberg, 2004), we cannot be certain that the same thing would obtain at the industry (or, country) level. The presumption that it would also hold for industry level data is based on the (implicit) assumption that the scale effect involves a symmetric adjustment for all pre-existing firms - i.e. a reduction in the output of all firms in the case of a wage rise. If, however, the adjustment involves expansion of some firms and closure for other firms it is theoretically possible, if relative factor use is not constant along each firm's outputexpansion path, for the expanding firms to increase their total demand for labour (at a reduced industry output) at a level above that which would obtain if only the substitution effect was in operation.
} 
specialization, ${ }^{35}$ and some further analysis which we have conducted has not revealed any connection between industrial specialization and country-level labour demand elasticities. ${ }^{36}$ Another possible explanation is differences in labour market flexibility. The hypothesis here is that in countries with rigid labor markets the response of employment to wage shocks will be more muted, implying a smaller labour demand elasticity (for various versions and tests of this hypothesis see, e.g. Bentolila and Bertola, 1990; Bertola and Rogerson, 1997; Blanchard and Portugal, 2001; Hasan et al., 2007). However, this does not appear to be borne by the data since there is no positive correlation between indices of labour market flexibility ${ }^{37}$ and the size of estimated elasticity. A final explanation we have considered is based on distinguishing between the stock and utilization measures of the labour input, which necessitates taking into account not just the number of persons employed but the hours worked as well (Hart and Moutos, 1995). For example, whereas the total hours worked by employees in all manufacturing industries in Germany dropped by 49 percent between 1970 and 2007, the number of employees declined by only 35 percent, implying a decline in hours worked per employee of about 14 percent $^{38}$ - part of which reflected a desire for more leisure by individual employees, whereas another part was union-mediated and it involved bargaining with the employers for work-sharing arrangements. The same was true in Spain, i.e. a reduction in hours worked per employee by about 15 percent. In contrast, in Greece, there was an increase in hours worked per employee by about 2

\footnotetext{
35 di Mauro and Forster (2008) also found that, in contrast to other advanced economies, euro area specialization patterns overall did not change since the much since the mid-1990s.

${ }^{36}$ For example, the high mean estimated value for Germany's labour-demand elasticity may not be attributed to the country's strong specialization in Fabricated Metals, or Motor Vehicles, Trailers, etc., since the value of the estimated elasticities for these industries are lower than the mean elasticity. Nevertheless, Germany's strong participation in the "slicing of the value chain" with Eastern European countries (Sinn, 2006) may explain the high value of the estimated elasticity.

${ }^{37}$ We have used the index for labour market flexibility as reported in Cunat and Melitz (2012), which is constructed by the World Bank on the basis of the methodology developed by Botero et al. (2004). The correlation coefficients between the values of the estimated elasticities and the index of labour market flexibility are either insignificant or negative.

${ }^{38}$ The EU KLEMS database provides data for the average number of hours worked per person, but this number includes the hours worked by the self-employed; according to this measure, the average number of hours worked per engaged person in manufacturing declined by 23 percent in Germany from 1970 to 2007.
} 
percent during the same period, whereas the corresponding number for Italy was a decline by 6 percent. Although these differences suggest that work-sharing arrangements may have influenced the size of the estimated country-specific elasticities, we lack the data needed (e.g. use of overtime, overtime premium) to formally examine whether this explanation has any merit.

\section{Conclusion}

Although the present study covers time-periods, data, and countries different from the studies surveyed by Hamermesh's (1993) summary of the empirical literature, his conclusion as to the plausible size of the own-price (conditional) elasticity of labour demand (stated in the Introduction) could well be the conclusion the present study as well. Given that most of the studies covered in Hamermesh's survey used data that ended by the early-eighties (i.e. data that predate the start of the modern era of globalization), the similarity in the values of the estimated elasticities may appear puzzling.

Before commenting on the expected influence of globalization on the conditional labour-demand elasticity, let us first discuss the case of unconditional elasticity. An important ingredient of what we have come to call globalization is the international fragmentation of economic activity (offshoring), which gives access to foreign factors of production, either directly in foreign affiliates or indirectly through intermediate inputs (Rauch and Trindale, 2003). Thus globalization can impact on the labour-demand elasticity by (i) increasing a firm's substitution possibilities between factor inputs, (ii) reducing the labour share, and (iii) increasing the elasticity of product demand. Since the unconditional elasticity of labour demand can be written as $\varepsilon=-\left(1-S_{L}\right) \sigma+S_{L} \theta$, where $\sigma$ is the elasticity of substitution between factors, $S_{L}$ is the share of labour in output and $\theta$ is the own-price elasticity of product demand, it is clear that the effect of globalization on the unconditional labour-demand elasticity is theoretically ambiguous. However, since the conditional labour demand elasticity can be expressed as $v=-\left(1-S_{L}\right) \sigma$, the above arguments would indicate an unambiguous rise in it due to 
globalization. Nevertheless, globalization may be bringing about changes in the composition of the work force within industries, which may have resulted in decreases (rather than increases, as hypothesized above) in the elasticity of substitution between labour and other factors. For example, due to the "slicing-of-the-value-chain", the skilled-labour intensity of the manufacturing sector may have increased in Eurozone countries, thus leading to a reduction in the elasticity of substitution since skilled workers tend to be complements rather than substitutes to other factors. This suggests that the relationship between the conditional labour-demand elasticity and globalization is not unambiguous.

Given our findings about the size of labour-demand elasticities, what can we conclude about the potency of the so-called internal devaluation to return the struggling periphery countries of the Eurozone (near) to pre-crisis employment levels? Before answering this question it is important to keep in mind that manufacturing employment is between 15 and 25 percent of total private-sector employment of these countries. Assuming that labour demand elasticities for the rest of the private sector are of similar magnitude, and that the product-demand curves do not shift, the estimated elasticities suggest that it is unlikely that the wage decreases already experienced will be enough, on their own, to restore private-sector employment to the pre-crisis levels for the countries that were still (i.e. in 2013) experiencing employment declines. ${ }^{39}$ Nevertheless, the results do indicate that the experienced wage declines can, when the contractionary credit and budgetary policies come to an end, have a non-negligible, albeit modest, effect on future employment growth.

\footnotetext{
${ }^{39}$ We re-iterate that although the estimated unconditional elasticities capture both substitution effects (i.e. moves along an isoquant as factor prices change) and scale effects (i.e. the change in the firm's output, and employment, in response to changes in costs along a given product-demand curve), they are not meant to capture shifts in the product-demand curve itself. However, due to the well-known homemarket bias of government purchases, the contractionary policies followed in the periphery countries of the Eurozone have resulted in inward shifts of the product-demand curves. Thus, the restoration of wage competitiveness for the periphery countries to their 1990s levels will not be enough - on its own - for a speedy recovery of their employment to the pre-crisis levels as soon as these wage adjustments are achieved.
} 


\section{References}

Bell, David N. F. and Robert A. Hart (1999). “Unpaid Work”, Economica, 66, 271-290.

Bentolila, Samuel, and Giuseppe Bertola (1990). "Firing Costs and Labour Demand: How Bad is Eurosclerosis?" Review of Economic Studies, 57, 381-402.

Berman, Eli J., John Bound, and Zvi Griliches (1994). "Changes in the demand for skilled labor within U.S. manufacturing: evidence from the annual survey of manufacturers." Quarterly Journal of Economics, 109, 367-398.

Bertola, Giuseppe, and Richard Rogerson (1997). "Institutions and Labor Reallocation." European Economic Review, 41, 1147-1171.

Blanchard, Olivier, and Pedro Portugal (2001). "What Hides behind an Unemployment Rate: Comparing Portuguese and US Labor Markets." American Economic Review, 91, 187-207.

Blanchflower, David G. and Andrew J. Oswald (1994). The Wage Curve. The MIT Press, Cambridge, Mass.

Botero, Juan, Simeon Djankov, Rafael La Porta, Florencio Lopez de Silanes, and Andrei Shleifer (2004). "The Regulation of Labor." Quarterly Journal of Economics, 119, 13391382.

Cahuc, Pierre, and Andre Zylberberg (2004). Labor Economics, The MIT Press, Cambridge, Mass.

Cunat, Alejandro, and Marc J. Melitz (2012). “Volatility, Labor Market Flexibility, and the Pattern of Comparative Advantage", Journal of the European Economic Association, 10, 225-254.

Darvas, Zsolt (2012). "Real Effective Exchange Rates for 178 Countries: A New Database." Bruegel Working Paper 06/12.

Di Mauro, Filippo, and Katrin Forster (2008). "Globalisation and the Competitiveness of the Euro Area", ECB Occasional Paper No. 97.

EEAG (2011). The EEAG Report on the European Economy. CESifo, Munich. 
EU KLEMS (2011), EU KLEMS Growth and Productivity Accounts, March 2011 Release, available at www.euklems.net .

Feenstra, Robert C., and Gordon Hanson (1996). "Globalization, offshoring and wage Inequality." American Economic Review, 86, 240-245.

Feenstra, Robert C., and Gordon Hanson (1999). "The impact of offshoring and high technology capital on wages: estimates for the United States, 1979-1990." The Quarterly Journal of Economics, 114, 907-940.

Feenstra, Robert C. and Alan M. Taylor (2008). International Economics, Worth Publishers, New York, New York.

Feenstra, Robert C. (2010). Offshoring in the Global Economy: Microeconomic Structure and Macroeconomic Implications, The MIT Press, Cambridge, Mass.

Griliches, Zvi, and Jerry A. Hausman (1986). “Errors in variables in panel data." Journal of Econometrics, 31, 93-118.

Hamermesh, Daniel (1993). Labor Demand. Princeton University Press, Princeton, New Jersey.

Hart, Robert A. (1987). Working Time and Employment. Allen \& Unwin, London.

Hart, Robert A. and Thomas Moutos (1995). Human Capital, Employment and Bargaining. Cambridge University Press, Cambridge, UK.

Hasan, Rana, Devashish Mitra, and K. V. Ramaswamy (2003). "Trade Reforms, Labor Regulations and Labor-Demand Elasticities: Empirical Evidence from India." NBER Working Paper No. 9879.

Hasan, Rana, Devashish Mitra, and K. V. Ramaswamy. (2007). "Trade Reforms, Labor Regulations and Labor Demand Elasticities: Empirical Evidence from India." Review of Economics \& Statistics, 89, 466-481.

Hausman, Jerry A. (1978). "Specification Tests in Econometrics." Econometrica, 46, 12511271.

Hijzen, Alexander and Paul Swaim (2010). Offshoring, labour market institutions and the elasticity of labour demand, European Economic Review 54, 1016-1034 
Krishna, Pravin, Devashish Mitra, and Sajjid Chinoy (2001). "Trade Liberaliza tion and Labor-Demand Elasticities: Evidence from Turkey," Journal of International Economics, 55, 391-409.

Lawrence, Charles, and Robert Z. Lawrence (1985). "Manufacturing wage dispersion: An end game interpretation." Brookings Papers on Economic Activity 1, 47-116.

O' Mahony, Mary and Marcel P. Timmer (2009). “Output, Input, and Productivity Measures at the Industry Level: The EU KLEMS Database." Economic Journal, F374-F403.

Krugman, Paul (1995). “ Growing World Trade: Causes and Consequences”, Brookings Papers on Economic Activity, 26, 327-377.

Panagariya, Arvind (1999). "Trade Openness: Consequences for the Elasticity of Demand for Labor and Wage Outcomes." available at: http://www.columbia.edu/ ap2231/technical\%20papers/LABORDD-3.pdf

Pierluigi, Beatrice, and Moreno Roma (2008). "Labour Cost and Employment across Euro Area Countries and Sectors." ECB Working Paper Series No 912.

Rauch, James E. and Vitor Trindade (2003). "Information, International Substitutability, and Globalization," American Economic Review, 93, 775-791.

Rodrik, Dani (1997). Has Globalization Gone Too Far? Institute for International Economics, Washington DC.

Senses, Mine Zeynep (2010). "The effects of offshoring on the elasticity of labor demand." Journal of International Economics, 81, 89-98.

Slaughter, Matthew J., (2001). "International trade and labor-demand elasticities." Journal of International Economics, 54, 27-56.

Sinn, Hans-Werner (2006). "The Pathological Export Boom and the Bazaar Effect: How to Solve the German Puzzle." The World Economy, 29, 1157-1175.

Wood, Adrian (1995). "How Trade Hurt Unskilled Workers" Journal of Economic Perspectives, 9, Summer, 57-80. 
Figure 1: Manufacturing Employment in the "Core" of EA12; 1970-2007, 1970=100

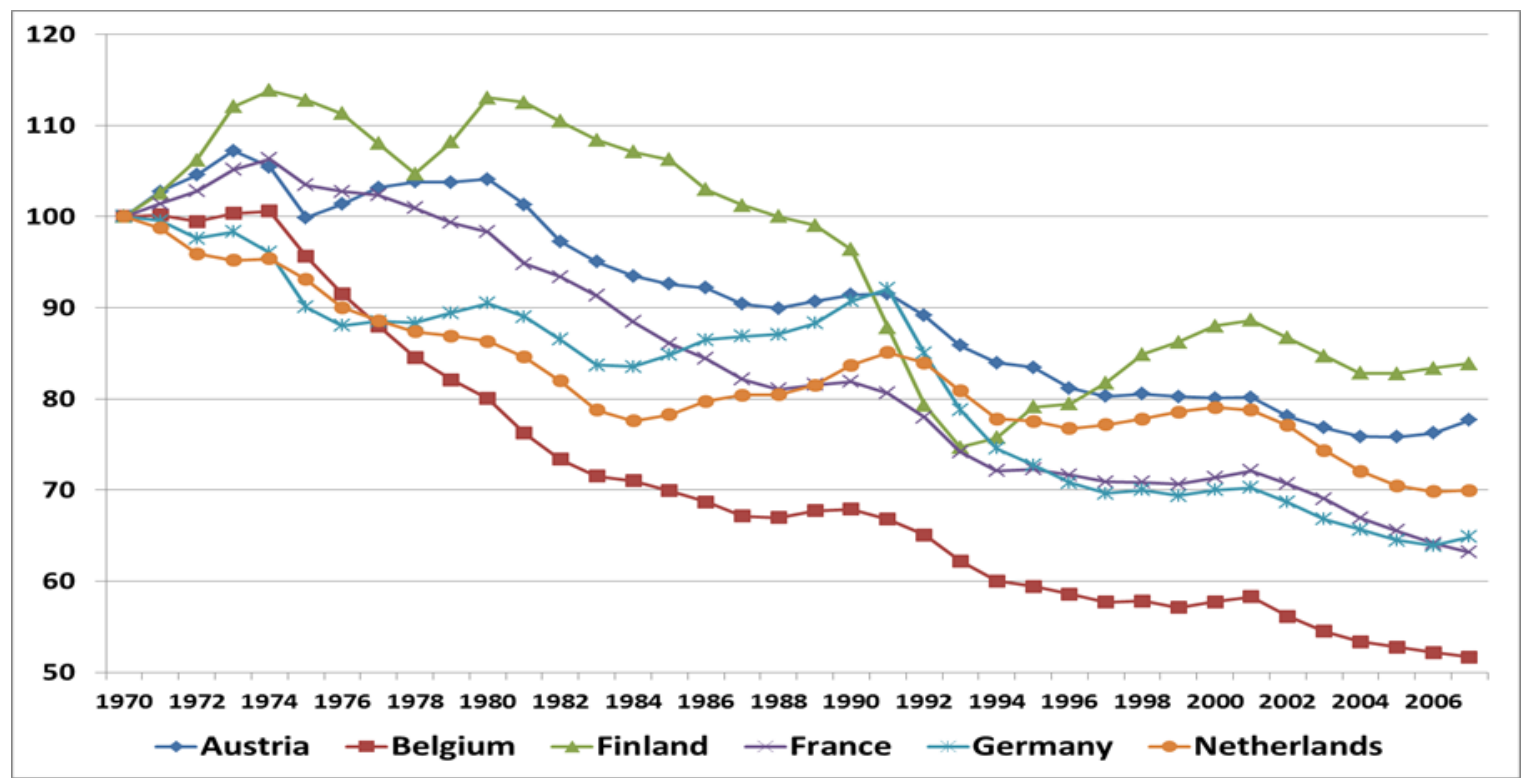

Source: KLEMS EU and authors' calculations

Figure 2: Manufacturing Employment in the "Periphery" of the EA12; 1970-2007, 1970=100

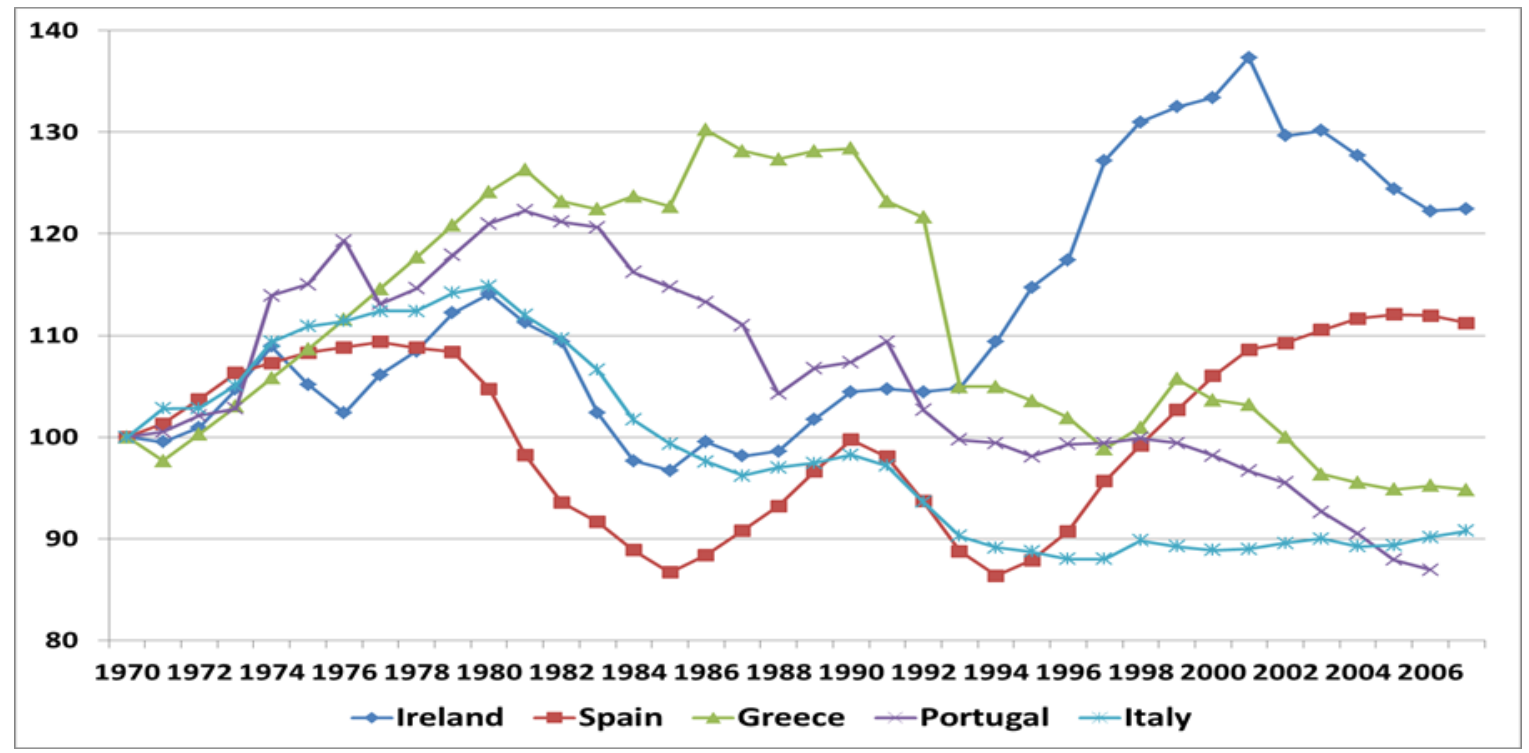

Source: KLEMS EU and authors' calculations 
Figure 3: Total Number of Employees in EA12 by Industry; 1970-2007, ‘000s

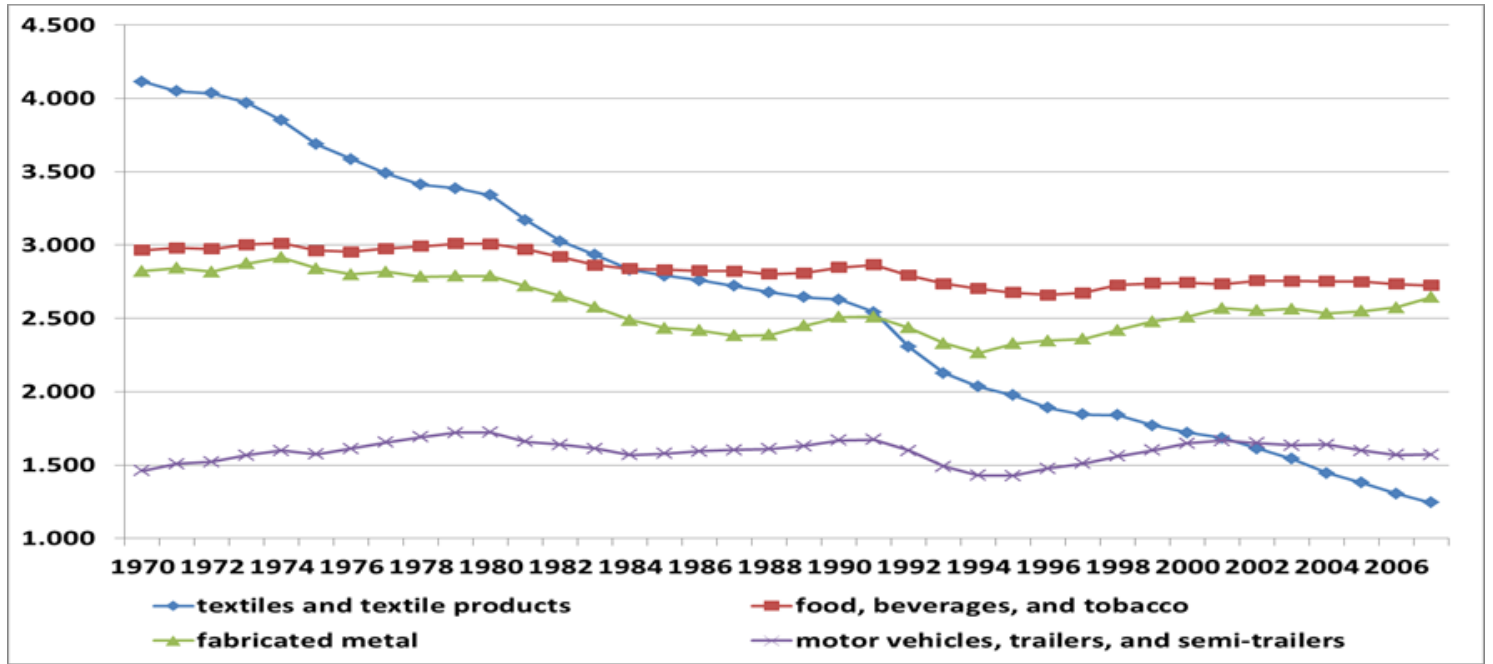

Source: EU KLEMS

Figure 4: Total Number of Employees in EA12 by industry; 1970-2007, ‘000s

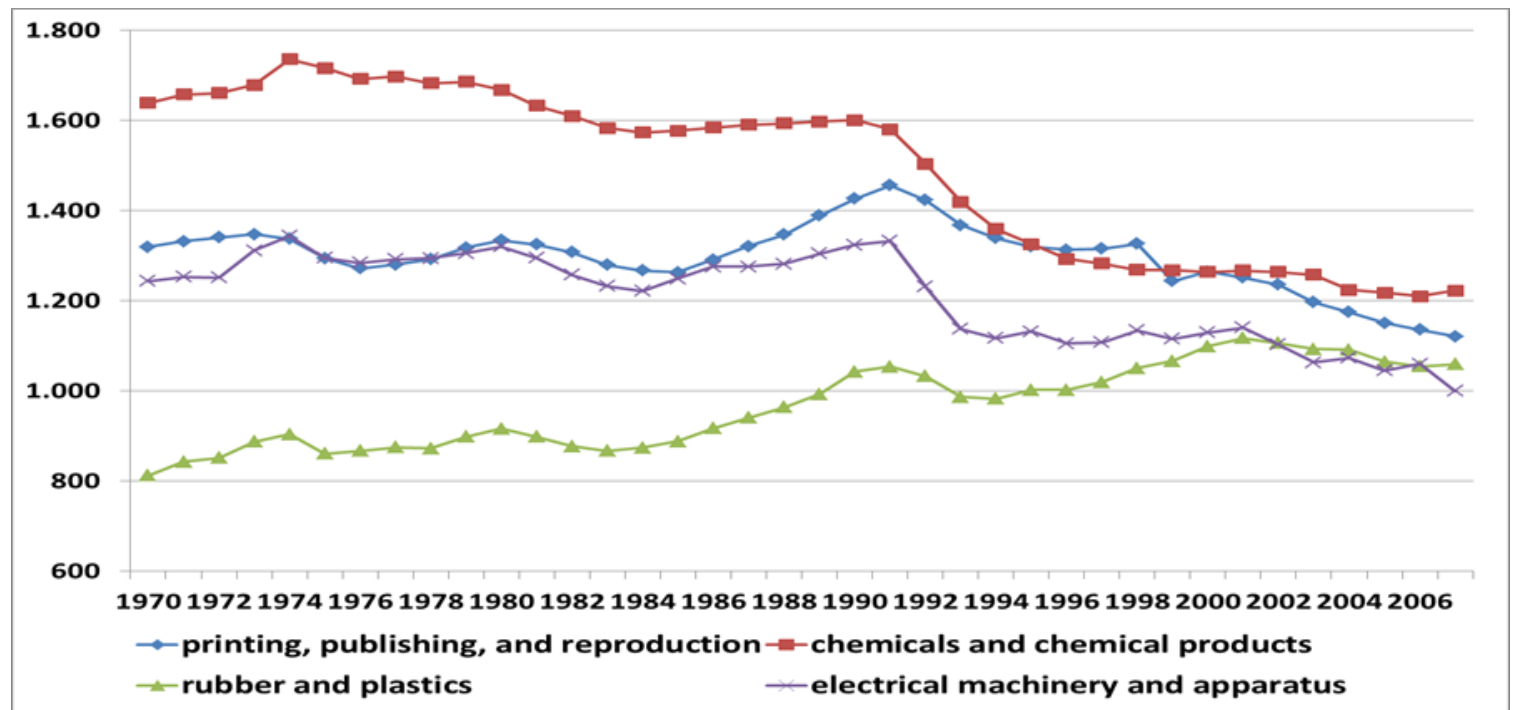

Source: EU KLEMS 
Figure 5: Ratio of Employee Compensation to Gross Value Added in EA12, 1970-2007, percent

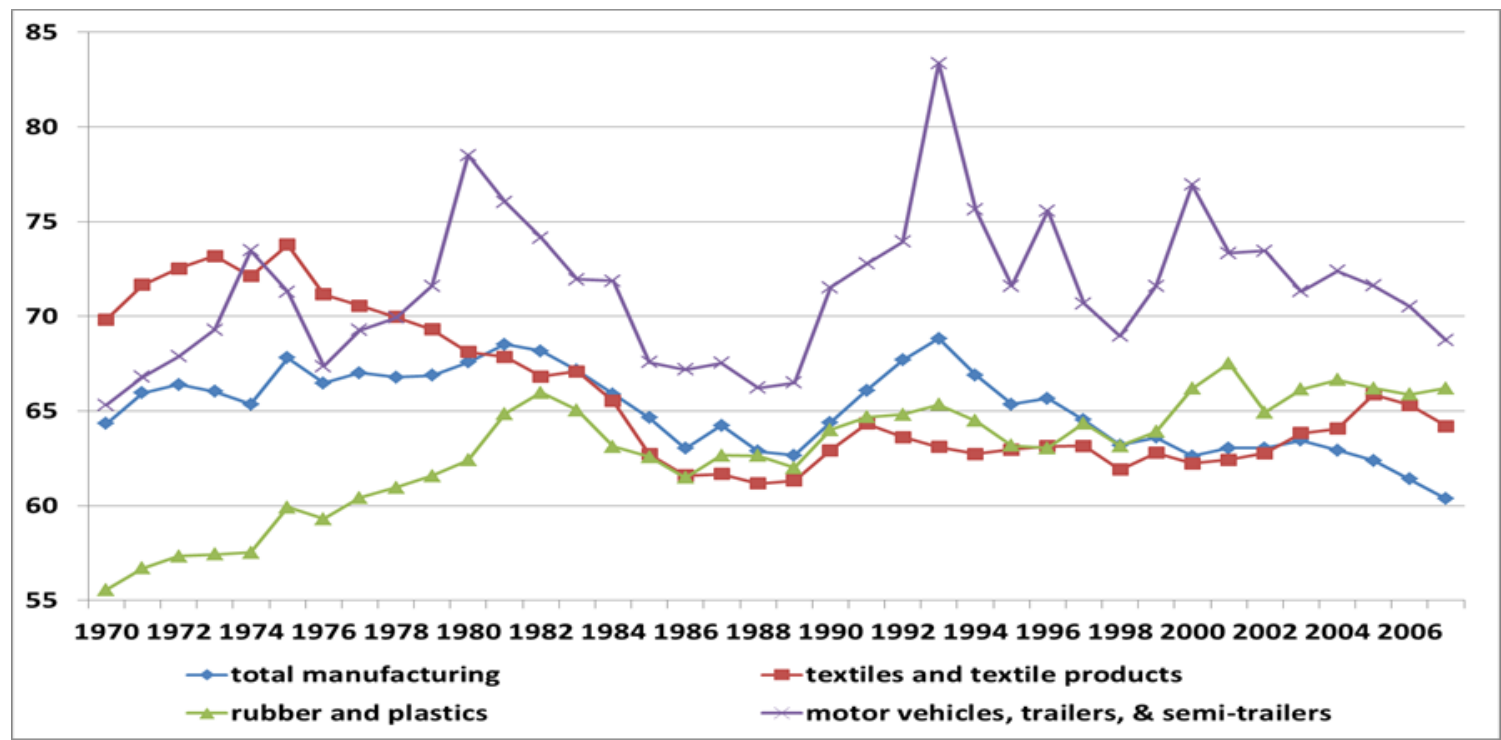

Source: EU KLEMS and authors' calculations

Figure 6: Ratio of Value of Intermediate Inputs to Value of Gross Output in EA12, percent

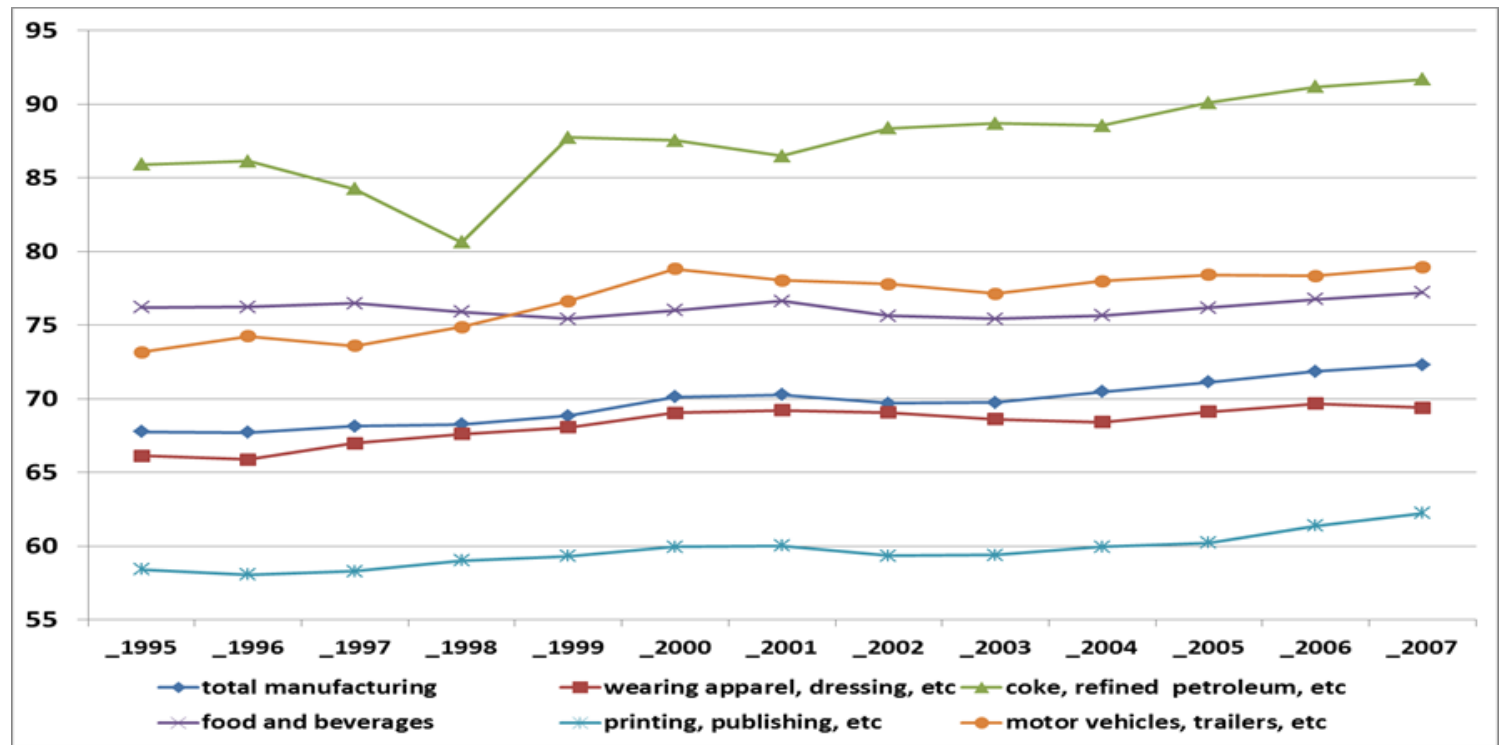

Source: EU KLEMS and authors' calculations 
Figure 7: Industries with Highest Employment Share in Total Employment, 1970-2007 Average

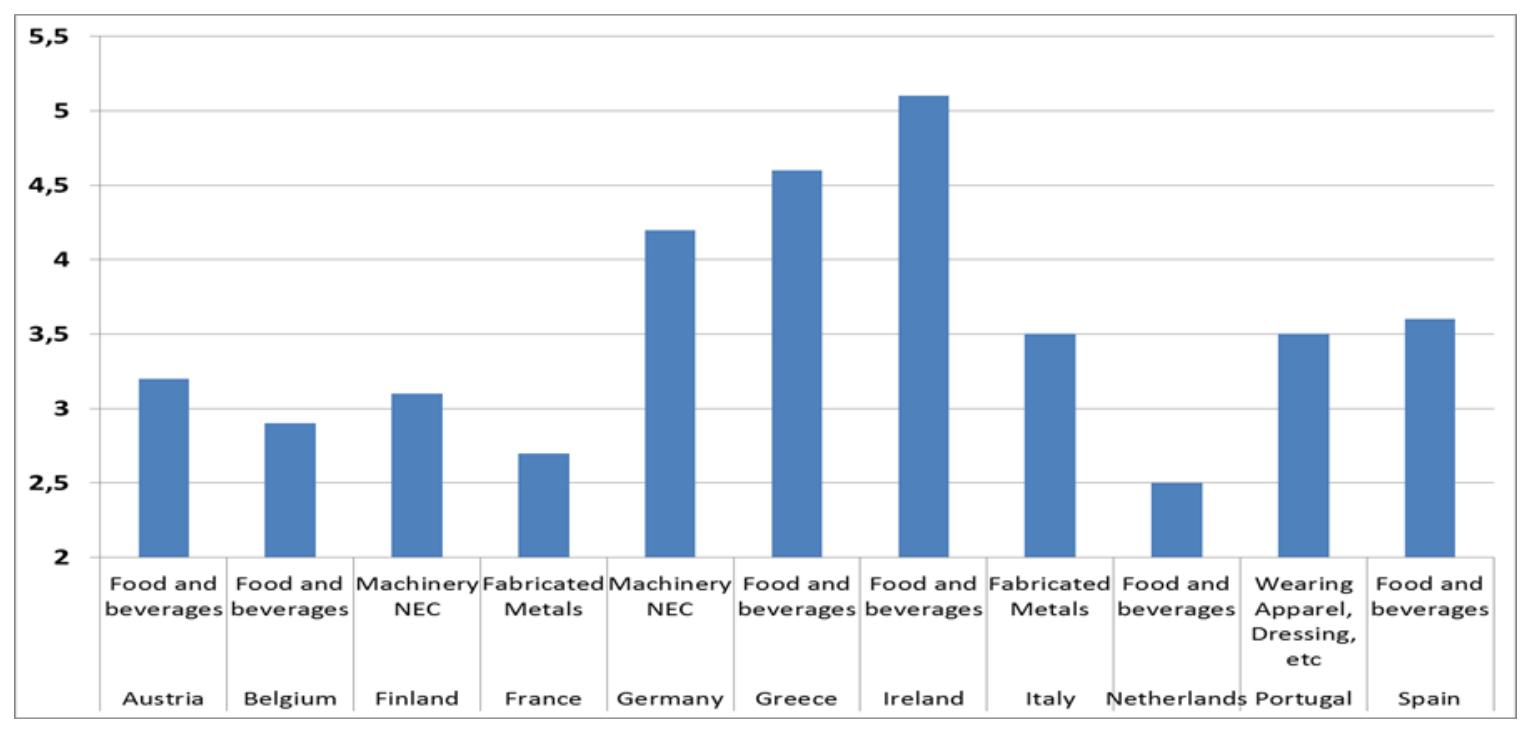

Source: EU KLEMS

Note: For Portugal, average of 1995-2006. 


\begin{tabular}{|c|c|c|c|c|}
\hline & Log(nominal wage) & Log(productivity) & Log(prices of Inputs) & Log (output) \\
\hline Food and beverages & $\begin{array}{l}-0.511^{* * *} \\
(-14.06)\end{array}$ & $\begin{array}{l}-0.193^{\star * *} \\
(-6.09)\end{array}$ & $\begin{array}{l}0.500^{\star \star \star} \\
(10.94)\end{array}$ & $\begin{array}{l}0.672^{* * *} \\
(12.04)\end{array}$ \\
\hline Textiles & $\begin{array}{l}-0.600^{* *} \\
(-3.01)\end{array}$ & $\begin{array}{l}-0.129 \\
(-0.44)\end{array}$ & $\begin{array}{l}0.820^{* * *} \\
(6.88)\end{array}$ & $\begin{array}{l}0.926^{\star \star} \\
(3.09)\end{array}$ \\
\hline Printing, publishing & $\begin{array}{l}-0.212^{* *} \\
(-2.08)\end{array}$ & $\begin{array}{l}0.251 \\
(0.56)\end{array}$ & $\begin{array}{l}0.294^{* *} \\
(2.58)\end{array}$ & $\begin{array}{l}0.127 \\
(0.34)\end{array}$ \\
\hline Chemicals and chemical & $\begin{array}{l}-0.287^{\star * *} \\
(-3.73)\end{array}$ & $\begin{array}{l}-0.214 \\
(-1.61)\end{array}$ & $\begin{array}{l}0.289^{* * *} \\
(4.24)\end{array}$ & $\begin{array}{l}0.675^{\star * *} \\
(4.78)\end{array}$ \\
\hline Rubber and plastics & $\begin{array}{l}-0.500^{* * *} \\
(-6.04)\end{array}$ & $\begin{array}{l}-0.303^{\star \star *} \\
(-4.31)\end{array}$ & $\begin{array}{l}0.468^{\star * \star} \\
(5.21)\end{array}$ & $\begin{array}{l}0.870^{\star * *} \\
(6.07)\end{array}$ \\
\hline Fabricated metal & $\begin{array}{l}-0.377^{\star *} \\
(-2.43)\end{array}$ & $\begin{array}{l}-0.261^{\star *} \\
(-2.57)\end{array}$ & $\begin{array}{l}0.463^{* * *} \\
(3.73)\end{array}$ & $\begin{array}{l}0.800^{* * *} \\
(4.56)\end{array}$ \\
\hline Electrical machinery & $\begin{array}{l}-0.357^{\star \star \star} \\
(-3.08)\end{array}$ & $\begin{array}{l}-0.166^{* *} \\
(-2.73)\end{array}$ & $\begin{array}{l}0.317^{* *} \\
(3.05)\end{array}$ & $\begin{array}{l}0.482^{\star \star \star} \\
(3.65)\end{array}$ \\
\hline Motor vehicles, trail & $\begin{array}{l}-0.434^{* *} \\
(-2.28)\end{array}$ & $\begin{array}{l}0.052 \\
(0.47)\end{array}$ & $\begin{array}{l}0.459^{* \star} \\
(2.98)\end{array}$ & $\begin{array}{l}0.501^{* * *} \\
(3.65)\end{array}$ \\
\hline \multicolumn{5}{|c|}{ 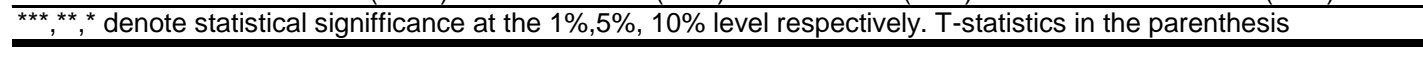 } \\
\hline 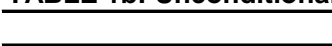 & Log(real wage) & Log(productivity) & Log(real prices of Inputs) & Log (REER) \\
\hline Food and beverages & $\begin{array}{l}-0.698^{\star * *} \\
(-7.61)\end{array}$ & $\begin{array}{l}0.565^{\star \star \star} \\
(14.51)\end{array}$ & $\begin{array}{l}-1.677^{\star \star \star} \\
(-3.61)\end{array}$ & $\begin{array}{l}-0.020 \\
(-0.13)\end{array}$ \\
\hline Textiles & $\begin{array}{l}-0.956^{\star * *} \\
(-13.64)\end{array}$ & $\begin{array}{l}0.884^{* * *} \\
(9.16)\end{array}$ & $\begin{array}{l}-0.851^{*} \\
(-1.81)\end{array}$ & $\begin{array}{l}0.297^{*} \\
(1.85)\end{array}$ \\
\hline Printing, publishing & $\begin{array}{l}-0.466^{\star *} \\
(-2.75)\end{array}$ & $\begin{array}{l}0.496^{* * *} \\
(5.96)\end{array}$ & $\begin{array}{l}-1.096^{\star \star *} \\
(-4.31)\end{array}$ & $\begin{array}{l}0.053 \\
0.32\end{array}$ \\
\hline Chemicals and chemical & $\begin{array}{l}-0.395^{\star \star *} \\
(-4.18)\end{array}$ & $\begin{array}{l}0.460^{* * *} \\
(10.96)\end{array}$ & $\begin{array}{l}-0.779^{\star \star *} \\
(-3.60)\end{array}$ & $\begin{array}{l}0.131 \\
(1.01)\end{array}$ \\
\hline Rubber and plastics & $\begin{array}{l}-0.417^{* * *} \\
(-3.21)\end{array}$ & $\begin{array}{l}0.281^{*} \\
(1.89)\end{array}$ & $\begin{array}{l}-0.301^{*} \\
(-1.80)\end{array}$ & $\begin{array}{l}-0.001 \\
(-0.01)\end{array}$ \\
\hline Fabricated metal & $\begin{array}{l}-0.874^{* * *} \\
(-6.24)\end{array}$ & $\begin{array}{l}0.788^{* * *} \\
(8.36)\end{array}$ & $\begin{array}{l}-1.028^{\star * *} \\
(-6.83)\end{array}$ & $\begin{array}{l}-0.091 \\
(-0.42)\end{array}$ \\
\hline Electrical machinery & $\begin{array}{l}-0.277^{\star *} \\
(-2.20)\end{array}$ & $\begin{array}{l}0.264^{* * *} \\
(3.15)\end{array}$ & $\begin{array}{l}-0.364^{* *} \\
(-2.03)\end{array}$ & $\begin{array}{l}-.193 \\
(-0.97)\end{array}$ \\
\hline Motor vehicles, trail & $\begin{array}{l}-0.599^{* * *} \\
(-6.53)\end{array}$ & $\begin{array}{l}0.627^{* \star *} \\
(8.89)\end{array}$ & $\begin{array}{l}-1.837^{* * *} \\
(-7.00) \\
\end{array}$ & $\begin{array}{l}-0.030 \\
(-0.18) \\
\end{array}$ \\
\hline \multicolumn{2}{|c|}{ TABLE 1c: Unconditional Labour Demand for Selected Industries } & Log(productivity) & Log(prices of Inputs) & Log (REER) \\
\hline Food and beverages & $\begin{array}{l}-0.359^{*} \\
(-1.91)\end{array}$ & $\begin{array}{l}0.184 \\
(1.52)\end{array}$ & $\begin{array}{l}0.382^{* \star} \\
(2.13)\end{array}$ & $\begin{array}{l}0.180 \\
(0.60)\end{array}$ \\
\hline Textiles & $\begin{array}{l}-0.616^{* *} \\
(-2.15)\end{array}$ & $\begin{array}{l}0.647^{* * *} \\
(4.08)\end{array}$ & $\begin{array}{l}0.740^{\star * *} \\
(4.28)\end{array}$ & $\begin{array}{l}0.277 \\
(1.09)\end{array}$ \\
\hline Printing, publishing & $\begin{array}{l}-0.017 \\
(-0.10)\end{array}$ & $\begin{array}{l}0.331^{* * *} \\
(4.96)\end{array}$ & $\begin{array}{l}0.047 \\
(0.25)\end{array}$ & $\begin{array}{l}0.135 \\
(0.51)\end{array}$ \\
\hline Chemicals and chemical & $\begin{array}{l}0.001 \\
(0.01)\end{array}$ & $\begin{array}{l}0.282^{* *} \\
(3.05)\end{array}$ & $\begin{array}{l}0.028 \\
(0.18)\end{array}$ & $\begin{array}{l}-0.001 \\
(-0.01)\end{array}$ \\
\hline Rubber and plastics & $\begin{array}{l}-0.182 \\
(-1.62)\end{array}$ & $\begin{array}{l}0.020 \\
(0.19)\end{array}$ & $\begin{array}{l}0.116 \\
(0.93)\end{array}$ & $\begin{array}{l}-0.059 \\
(-0.22)\end{array}$ \\
\hline Fabricated metal & $\begin{array}{l}-0.199 \\
(-1.24)\end{array}$ & $\begin{array}{l}0.169 \\
(4.91)\end{array}$ & $\begin{array}{l}0.187^{\star} \\
(1.81)\end{array}$ & $\begin{array}{l}-0.244 \\
(-1.06)\end{array}$ \\
\hline Electrical machinery & $\begin{array}{l}-0.122^{*} \\
(-1.74)\end{array}$ & $\begin{array}{l}0.099^{* *} \\
(2.86)\end{array}$ & $\begin{array}{l}0.010 \\
(0.21)\end{array}$ & $\begin{array}{l}0.100 \\
(0.34)\end{array}$ \\
\hline Motor vehicles, trail & $\begin{array}{l}-0.259 \\
(-1.27)\end{array}$ & $\begin{array}{l}0.396^{\star \star \star} \\
(4.59)\end{array}$ & $\begin{array}{l}0.158 \\
(1.03)\end{array}$ & $\begin{array}{l}0.334 \\
(0.99)\end{array}$ \\
\hline
\end{tabular}


TABLE 2: OLS results

\begin{tabular}{|c|c|c|c|c|c|c|}
\hline \multirow[b]{2}{*}{ industry } & \multicolumn{2}{|c|}{ Conditional Elasticities } & \multicolumn{2}{|c|}{ Unconditional Elasticities. } & \multicolumn{2}{|c|}{$\frac{\text { Unconditional Elasticities- }}{\text { Nominal variables }}$} \\
\hline & elasticity & standard error & elasticity & $\begin{array}{l}\text { standard } \\
\text { error }\end{array}$ & elasticity & standard error \\
\hline Food and beverages & -0.5108 & 0.001 & -0.6979 & 0.008 & -0.3596 & 0.035 \\
\hline Tobacco & -0.3075 & 0.024 & -0.3775 & 0.007 & -0.2256 & 0.012 \\
\hline Textiles & -0.5997 & 0.040 & -0.9562 & 0.005 & -0.6156 & 0.082 \\
\hline Wearing Apparel, Dres & -0.6867 & 0.043 & -1.1166 & 0.008 & -0.4175 & 0.155 \\
\hline Leather, leather and & -0.6723 & 0.031 & -0.8005 & 0.014 & -0.4344 & 0.048 \\
\hline WOOD AND OF WOOD AND & -0.4206 & 0.007 & -0.6758 & 0.008 & -0.2134 & 0.024 \\
\hline Pulp, paper and paper & -0.4056 & 0.047 & -0.4526 & 0.021 & -0.2787 & 0.022 \\
\hline Printing, publishing & -0.2116 & 0.010 & -0.4663 & 0.029 & -0.0172 & 0.032 \\
\hline Coke, refined petrole & -0.2506 & 0.009 & -0.2516 & 0.004 & -0.2101 & 0.006 \\
\hline Chemicals and chemica & -0.2874 & 0.006 & -0.3950 & 0.009 & 0.0014 & 0.017 \\
\hline Rubber and plastics & -0.4985 & 0.007 & -0.4170 & 0.017 & -0.1830 & 0.013 \\
\hline OTHER NON-METALLIC MI & -0.4755 & 0.038 & -0.6380 & 0.019 & -0.4098 & 0.020 \\
\hline Basic metals & -0.2596 & 0.006 & -0.5705 & 0.049 & 0.0855 & 0.017 \\
\hline Fabricated metal & -0.3767 & 0.024 & -0.8738 & 0.020 & -0.1989 & 0.026 \\
\hline MACHINERY, NEC & -0.3724 & 0.006 & -0.7556 & 0.006 & -0.1828 & 0.006 \\
\hline Office, accounting an & -0.4065 & 0.039 & -0.4674 & 0.005 & -0.0220 & 0.015 \\
\hline Electrical machinery & -0.3566 & 0.013 & -0.2768 & 0.016 & -0.1224 & 0.005 \\
\hline Radio, television and & -0.5854 & 0.008 & -0.5811 & 0.004 & -0.4525 & 0.029 \\
\hline Medical, precision an & -0.3411 & 0.018 & -0.6082 & 0.004 & -0.1153 & 0.025 \\
\hline Motor vehicles, trail & -0.4343 & 0.036 & -0.5989 & 0.008 & -0.2586 & 0.042 \\
\hline Other transport equip & -0.4424 & 0.019 & -0.5421 & 0.008 & -0.2969 & 0.022 \\
\hline Manufacturing nec & -0.2560 & 0.041 & -0.4328 & 0.033 & -0.0225 & 0.024 \\
\hline Recycling & -0.7816 & 0.022 & -0.6535 & 0.023 & -0.6531 & 0.024 \\
\hline
\end{tabular}


TABLE 3: OLS Results, 3- Year Differences

\begin{tabular}{|c|c|c|c|c|c|c|}
\hline \multirow[b]{2}{*}{ industry } & \multicolumn{2}{|c|}{ Conditional Elasticities } & \multicolumn{2}{|c|}{$\frac{\text { Unconditional }}{\frac{\text { Elasticities-Real }}{\text { variables }}}$} & \multicolumn{2}{|c|}{$\frac{\text { Unconditional Elasticities- }}{\text { Nominal variables }}$} \\
\hline & elasticity & standard error & elasticity & $\begin{array}{l}\text { standard } \\
\text { error }\end{array}$ & elasticity & standard error \\
\hline Food and beverages & $-0,3736$ & 0,003 & $-0,3146$ & 0,002 & $-0,3217$ & 0,002 \\
\hline Tobacco & $-0,5033$ & 0,022 & $-0,4871$ & 0,002 & $-0,5046$ & 0,022 \\
\hline Textiles & $-0,2526$ & 0,022 & $-0,2368$ & 0,014 & $-0,2513$ & 0,020 \\
\hline Wearing Apparel, Dres & $-0,5199$ & 0,033 & $-0,5183$ & 0,031 & $-0,5386$ & 0,036 \\
\hline Leather, leather and & $-0,4725$ & 0,007 & $-0,4350$ & 0,005 & $-0,4399$ & 0,008 \\
\hline WOOD AND OF WOOD AND & $-0,1958$ & 0,012 & $-0,2171$ & 0,005 & $-0,0764$ & 0,009 \\
\hline Pulp, paper and paper & $-0,2894$ & 0,006 & $-0,2795$ & 0,004 & $-0,2599$ & 0,006 \\
\hline Printing, publishing & $-0,2145$ & 0,010 & $-0,2914$ & 0,007 & $-0,2053$ & 0,009 \\
\hline Coke, refined petrole & $-0,0650$ & 0,001 & $-0,0582$ & 0,001 & $-0,0602$ & 0,001 \\
\hline Chemicals and chemica & $-0,0929$ & 0,002 & $-0,1216$ & 0,001 & $-0,0902$ & 0,002 \\
\hline Rubber and plastics & $-0,2634$ & 0,009 & $-0,2738$ & 0,006 & $-0,2027$ & 0,007 \\
\hline OTHER NON-METALLIC MI & $-0,2916$ & 0,002 & $-0,3251$ & 0,004 & $-0,2534$ & 0,003 \\
\hline Basic metals & $-0,1191$ & 0,002 & $-0,1008$ & 0,003 & $-0,0893$ & 0,002 \\
\hline Fabricated metal & $-0,2247$ & 0,004 & $-0,2693$ & 0,002 & $-0,1665$ & 0,003 \\
\hline MACHINERY, NEC & $-0,2603$ & 0,004 & $-0,3268$ & 0,003 & $-0,2513$ & 0,004 \\
\hline Office, accounting an & $-0,4717$ & 0,014 & $-0,4703$ & 0,013 & $-0,4517$ & 0,016 \\
\hline Electrical machinery & $-0,2740$ & 0,003 & $-0,2663$ & 0,002 & $-0,2384$ & 0,005 \\
\hline Radio, television and & $-0,2068$ & 0,002 & $-0,2294$ & 0,002 & $-0,1998$ & 0,002 \\
\hline Medical, precision an & $-0,2671$ & 0,006 & $-0,2361$ & 0,009 & $-0,2067$ & 0,006 \\
\hline Motor vehicles, trail & $-0,2500$ & 0,005 & $-0,1970$ & 0,001 & $-0,1841$ & 0,002 \\
\hline Other transport equip & $-0,4151$ & 0,020 & $-0,4962$ & 0,019 & $-0,4256$ & 0,024 \\
\hline Manufacturing nec & $-0,1479$ & 0,006 & $-0,2771$ & 0,003 & $-0,1160$ & 0,005 \\
\hline Recycling & $-0,1356$ & 0,027 & $-0,1969$ & 0,021 & $-0,1781$ & 0,034 \\
\hline
\end{tabular}


TABLE 4: OLS Results, 5-Year Differences

\begin{tabular}{|c|c|c|c|c|c|c|}
\hline & \multicolumn{2}{|c|}{$\begin{array}{l}\text { Conditional } \\
\text { Elasticities }\end{array}$} & \multicolumn{2}{|c|}{$\frac{\frac{\text { Unconditional }}{\text { Elasticities-Real }}}{\text { variables }}$} & \multicolumn{2}{|c|}{$\begin{array}{c}\begin{array}{c}\text { Unconditional } \\
\text { Elasticities-Nominal }\end{array} \\
\text { variables }\end{array}$} \\
\hline industry & elasticity & $\begin{array}{l}\text { standard } \\
\text { error }\end{array}$ & elasticity & $\begin{array}{l}\text { standard } \\
\text { error }\end{array}$ & elasticity & $\begin{array}{l}\text { standard } \\
\text { error }\end{array}$ \\
\hline Food and beverages & $-0,4467$ & 0,004 & $-0,4113$ & 0,005 & $-0,3955$ & 0,004 \\
\hline Tobacco & $-0,5000$ & 0,023 & $-0,4875$ & 0,001 & $-0,4987$ & 0,022 \\
\hline Textiles & $-0,1807$ & 0,030 & $-0,1856$ & 0,027 & $-0,1815$ & 0,028 \\
\hline Wearing Apparel, Dres & $-0,5216$ & 0,034 & $-0,5406$ & 0,034 & $-0,5331$ & 0,038 \\
\hline Leather, leather and & $-0,4580$ & 0,008 & $-0,4062$ & 0,007 & $-0,4287$ & 0,008 \\
\hline WOOD AND OF WOOD AND & $-0,2385$ & 0,013 & $-0,2298$ & 0,007 & $-0,1243$ & 0,010 \\
\hline Pulp, paper and paper & $-0,2777$ & 0,005 & $-0,2638$ & 0,005 & $-0,2469$ & 0,005 \\
\hline Printing, publishing & $-0,2167$ & 0,013 & $-0,2922$ & 0,009 & $-0,2134$ & 0,010 \\
\hline Coke, refined petrole & $-0,0592$ & 0,001 & $-0,0478$ & 0,001 & $-0,0536$ & 0,001 \\
\hline Chemicals and chemica & $-0,0598$ & 0,004 & $-0,1011$ & 0,002 & $-0,0582$ & 0,003 \\
\hline Rubber and plastics & $-0,3033$ & 0,015 & $-0,3182$ & 0,010 & $-0,2465$ & 0,011 \\
\hline OTHER NON-METALLIC MI & $-0,2980$ & 0,004 & $-0,3403$ & 0,007 & $-0,2814$ & 0,005 \\
\hline Basic metals & $-0,0821$ & 0,005 & $-0,0610$ & 0,006 & $-0,0546$ & 0,005 \\
\hline Fabricated metal & $-0,2611$ & 0,007 & $-0,3204$ & 0,003 & $-0,1894$ & 0,004 \\
\hline MACHINERY, NEC & $-0,2832$ & 0,005 & $-0,3383$ & 0,002 & $-0,2600$ & 0,003 \\
\hline Office, accounting an & $-0,4721$ & 0,014 & $-0,4926$ & 0,011 & $-0,4618$ & 0,014 \\
\hline Electrical machinery & $-0,2745$ & 0,006 & $-0,2864$ & 0,004 & $-0,2374$ & 0,007 \\
\hline Radio, television and & $-0,1694$ & 0,003 & $-0,1820$ & 0,003 & $-0,1593$ & 0,003 \\
\hline Medical, precision an & $-0,2746$ & 0,009 & $-0,2312$ & 0,009 & $-0,2141$ & 0,008 \\
\hline Motor vehicles, trail & $-0,2811$ & 0,016 & $-0,1926$ & 0,005 & $-0,1831$ & 0,004 \\
\hline Other transport equip & $-0,3987$ & 0,026 & $-0,4893$ & 0,022 & $-0,4192$ & 0,029 \\
\hline Manufacturing nec & $-0,1937$ & 0,011 & $-0,3361$ & 0,005 & $-0,1676$ & 0,009 \\
\hline Recycling & 0,2222 & 0,078 & 0,0817 & 0,034 & 0,1913 & 0,051 \\
\hline
\end{tabular}




\begin{tabular}{|c|c|c|c|c|c|c|}
\hline \multicolumn{7}{|c|}{ TABLE 5a: OLS Results } \\
\hline & \multicolumn{2}{|c|}{ Conditional Elasticities } & \multicolumn{2}{|c|}{$\frac{\text { Elasticities-Real }}{\text { variables }}$} & \multicolumn{2}{|c|}{$\frac{\text { Unconditional Elasticities- }}{\text { Nominal variables }}$} \\
\hline country & elasticity & standard error & \multicolumn{2}{|c|}{$\begin{array}{ll} & \text { standard } \\
\text { city } & \text { error } \\
\end{array}$} & \multicolumn{2}{|c|}{$\begin{array}{ll} & \text { standard } \\
\text { elasticity } & \text { error } \\
\end{array}$} \\
\hline Austria & 0,4107 & 0,386 & $-0,5935$ & 0,051 & 0,3373 & 0,372 \\
\hline Belgium & $-0,0618$ & 0,008 & $-0,1919$ & 0,008 & $-0,0370$ & 0,005 \\
\hline Finland & $-0,1510$ & 0,014 & $-0,4392$ & 0,018 & 0,0066 & 0,087 \\
\hline France & $-0,8370$ & 0,014 & $-0,1592$ & 0,006 & $-0,5631$ & 0,006 \\
\hline Germany & $-1,1727$ & 0,033 & $-0,4254$ & 0,017 & $-0,7154$ & 0,075 \\
\hline Greece & $-0,2591$ & 0,015 & $-0,1151$ & 0,014 & $-0,1196$ & 0,012 \\
\hline Ireland & $-0,5988$ & 0,013 & $-0,5807$ & 0,012 & $-0,6064$ & 0,011 \\
\hline Italy & $-0,9707$ & 0,039 & $-0,2693$ & 0,031 & $-0,8548$ & 0,081 \\
\hline Netherlands & $-0,7009$ & 0,032 & $-0,4299$ & 0,031 & $-0,3792$ & 0,040 \\
\hline Portugal & $-0,3490$ & 0,037 & 0,0609 & 0,035 & $-0,3062$ & 0,061 \\
\hline \multirow[t]{3}{*}{ Spain } & $-0,4032$ & 0,046 & $-0,6669$ & 0,022 & $-0,3092$ & 0,041 \\
\hline & TABLE 5b & p: OLS Results- & - 3- Year Di & ices & & \\
\hline & \multicolumn{4}{|c|}{$\frac{\text { Unconditional }}{\text { Elasticities-Real }}$} & \multicolumn{2}{|c|}{$\frac{\text { Unconditional Elasticities- }}{\text { Nominal variables }}$} \\
\hline country & elasticity & standard error & elasticity & $\begin{array}{l}\text { standard } \\
\text { error }\end{array}$ & \multicolumn{2}{|c|}{$\begin{array}{l}\text { standard } \\
\text { error } \\
\end{array}$} \\
\hline Austria & $-0,44283$ & 0,019 & $-0,35425$ & 0,010131 & $-0,4419$ & 0,020 \\
\hline Belgium & $-0,0661$ & 0,002 & $-0,0708$ & 0,001 & $-0,0629$ & 0,001 \\
\hline Finland & $-0,2938$ & 0,008 & $-0,1878$ & 0,015 & $-0,1805$ & 0,021 \\
\hline France & $-0,1225$ & 0,019 & $-0,1240$ & 0,015 & $-0,1224$ & 0,020 \\
\hline Germany & $-0,7474$ & 0,010 & $-0,4571$ & 0,005 & $-0,7171$ & 0,014 \\
\hline Greece & $-0,2509$ & 0,018 & $-0,2333$ & 0,016 & $-0,2372$ & 0,017 \\
\hline Ireland & $-0,2131$ & 0,006 & $-0,2125$ & 0,005 & $-0,2055$ & 0,005 \\
\hline Italy & $-0,1328$ & 0,009 & $-0,0237$ & 0,003 & $-0,0771$ & 0,008 \\
\hline Netherlands & $-0,3321$ & 0,031 & $-0,2274$ & 0,017 & $-0,3195$ & 0,031 \\
\hline Portugal & $-0,2265$ & 0,003 & $-0,2448$ & 0,003 & $-0,2169$ & 0,004 \\
\hline \multirow[t]{4}{*}{ Spain } & $-0,5149$ & 0,022 & $-0,4749$ & 0,021 & $-0,4852$ & 0,023 \\
\hline & TABLE 50 & c: OLS Results- & - 5-Year Dif & ferences & & \\
\hline & \multicolumn{4}{|c|}{ Unconditional } & \multirow{2}{*}{\multicolumn{2}{|c|}{$\frac{\text { Unconditional Elasticities- }}{\text { Nominal variables }}$}} \\
\hline & \multicolumn{2}{|c|}{ Conditional Elasticities } & \multicolumn{2}{|c|}{$\frac{\text { Elasticities-Real }}{\text { variables }}$} & & \\
\hline country & elasticity & standard error & elasticity & $\begin{array}{l}\text { standard } \\
\text { error }\end{array}$ & elasticity & $\begin{array}{l}\text { standard } \\
\text { error }\end{array}$ \\
\hline Austria & $-0,3356$ & 0,012 & $-0,3024$ & 0,005643 & $-0,3363$ & 0,012 \\
\hline Belgium & $-0,0389$ & 0,001 & $-0,0679$ & 0,001 & $-0,0338$ & 0,001 \\
\hline Finland & $-0,2976$ & 0,012 & $-0,1890$ & 0,019 & $-0,1842$ & 0,031 \\
\hline France & $-0,0939$ & 0,016 & $-0,1097$ & 0,016 & $-0,1028$ & 0,019 \\
\hline Germany & $-0,7233$ & 0,009 & $-0,4743$ & 0,003 & $-0,7012$ & 0,012 \\
\hline Greece & $-0,2729$ & 0,018 & $-0,2311$ & 0,016 & $-0,2410$ & 0,017 \\
\hline Ireland & $-0,1954$ & 0,006 & $-0,1860$ & 0,005 & $-0,1799$ & 0,005 \\
\hline Italy & $-0,1751$ & 0,013 & 0,0001 & 0,004 & $-0,1050$ & 0,010 \\
\hline Netherlands & $-0,3653$ & 0,034 & $-0,2669$ & 0,020 & $-0,3654$ & 0,034 \\
\hline Portugal & $-0,3238$ & 0,008 & $-0,3288$ & 0,005 & $-0,3059$ & 0,009 \\
\hline Spain & $-0,5378$ & 0,025 & $-0,4931$ & 0,024 & $-0,5079$ & 0,025 \\
\hline
\end{tabular}

